\title{
The Early Basilica Church, El-Ashmonein Archaeological Site, Minia, Egypt: Geo-Environmental Analysis and Engineering Characterization of the Building Materials
}

\author{
Sayed Hemeda1 ${ }^{(1)}$, Abdulrahman Fahmy', Abbas Moustafa², Mahmoud Abd El Hafez ${ }^{1}$ \\ ${ }^{1}$ Conservation Department, Faculty of Archaeology, Cairo University, Giza, Egypt \\ ${ }^{2}$ Civil Engineering Department, Minia University, Minia, Egypt \\ Email: sayed.hemeda@cu.edu.eg
}

How to cite this paper: Hemeda, S., Fahmy, A., Moustafa, A. and El Hafez, M.A. (2019) The Early Basilica Church, El-Ashmonein Archaeological Site, Minia, Egypt: GeoEnvironmental Analysis and Engineering Characterization of the Building Materials. Open Journal of Geology, 9, 157-186. https://doi.org/10.4236/ojg.2019.93011

Received: February 10, 2019

Accepted: March 12, 2019

Published: March 15, 2019

Copyright $\odot 2019$ by author(s) and Scientific Research Publishing Inc. This work is licensed under the Creative Commons Attribution International License (CC BY 4.0).

http://creativecommons.org/licenses/by/4.0/

(c) (i) Open Access

\begin{abstract}
El-Ashmonein is a significant archaeological site with different buildings from various eras. Between the villages of El-Idara and El-Ashmonein are there mains of Hermopolis, one of the ancient Egyptian metropolis capitals of the fifteenth century of Upper Egypt, called the hare. The buildings in this archaeological site are exposed to many causes of destruction and damage. The remaining structures and granite free standing columns in this area are suffered from plenty of geo-environmental and geotechnical problems. The main objectives of this study are 1) to assess the current state of preservation of this important archaeological site, especially the basilica church with its free standing huge columns, 2) to analyze the different actions which cause the destruction of the archaeological site, in particular the old flash floods and earthquakes, and 3) to identify the geochemical and engineering properties of the construction materials of the granitic columns and other limestone structures of the basilica church by using different kind of sophisticated analytical and diagnostic tools and methods. The multi-criteria analysis allowed the integration of several elements for mapping the vulnerable zones. Results revealed that about $80 \%$ of the study area was exposed to high and medium old floods vulnerability because of the vicinity to the Nile River. The structural and non-structural measures recommended in this research will help the decision makers and planners to effectively develop strategies for future site management, intervention retrofitting and rehabilitation of this unique archaeological site.
\end{abstract}

\section{Keywords}

El-Ashmonein, Basilica Church, Flash Floods, Construction Materials, 
Engineering Characterization

\section{Introduction}

El-Ashmonein is a small village located in Mellway District of Miniagovernerate, which is about $246 \mathrm{~km}$ from Cairo, situated on the western bank of Nile river, 27 $\mathrm{m}$ elevation and one of the ancient Egyptian metropolis capitals of the fifteenth century of Upper Egypt is called the "hare" [1] as shown in Figure 1 (old map for different old cities including El-Ashmonein archaeological site) and Figure 2 (cross section for Mellawy by using GIS software including El-Ashmonein). El-Ashmonein archaeological site contains several old temples such as Thoth temple, Roman temples and Basilica church. But the importance of this archaeological site has not received significant attention since it needs protection and repairs. Therefore, the objectives of this research highlight the importance of this archaeological site, the reasons of the destruction of the archeological site including the focal study upon Basilica church, the current state of preservation for the archaeological site, identification of the construction materials of the free-standing stone columns of the Basilica church, and identification of the geochemical, physical and mechanical characterizations of the construction materials. The authors visited the archaeological site of El-Ashmonein for engineering surveying, taking pictures, sampling and understanding the current state of preservation for the archaeological site.

Several authors spoke about this archaeological site such as A. J. Spencer (1982). In this year, the excavations by the British Museum in the temple of Thoth at El-Ashmonein revealed building remains consisting of the lower courses of a wall and one side of a door, with an adjacent area of limestone paving [2]. According to Jeffrey Spencer (1983), this volume of book contains the results of a survey carried out by the British museum expedition on the archaeological site of El-Ashmonein the ancient Hermopolis Magna in middle Egypt. The results of the survey are shown in new map of the site, showing the topography of the site itself. The survey objective was to put a framework for the future discoveries. It was told that the earliest attempt to record the topography of this site was made by the French expedition of 1798, and, although this plan provided a useful record of the state of the mounds at that time the surface details are now altered [3]. Marek Barański (1987-1990) said that the church (basilica) building with atrium and adjacent rooms formed an independent complex set in the very center of the ancient town. The building of the basilica destroyed structures previously existing on the spot. Unfortunately, after the collapse of the basilica, its remnants were partly dismantled in quest for limestone blocks the excavations carried out in the forties discovered that the basilica foundations were constructed of blocks and elements of decoration taken from Hellenistic buildings [4]. Magdy Mansour Badway (1996) added in columns development if the architecture is built for the purpose of shelter, governance, entertainment, 


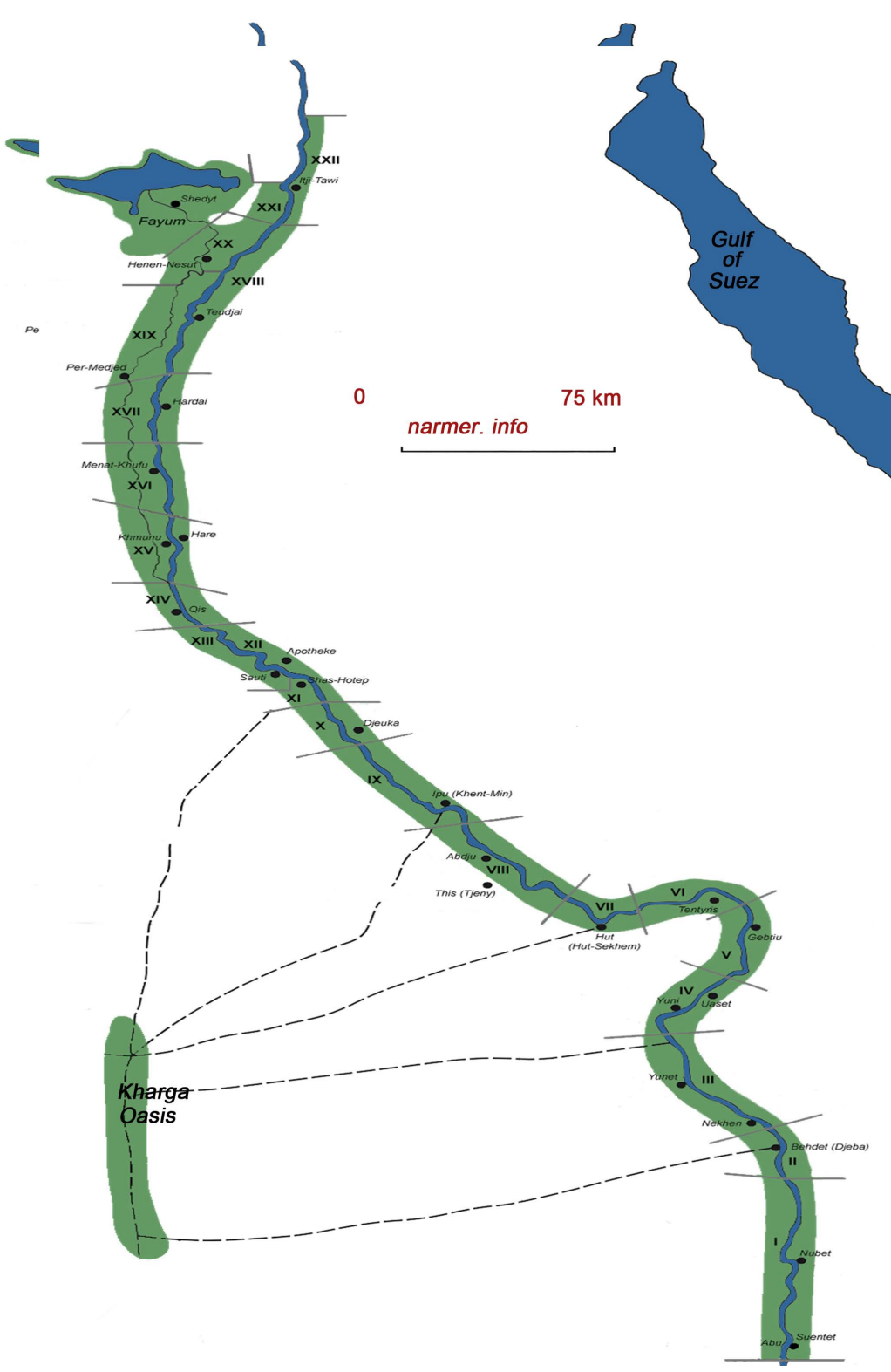

Figure 1. Map of the old cities in Egypt, including El-Ashmounein archaeological site.

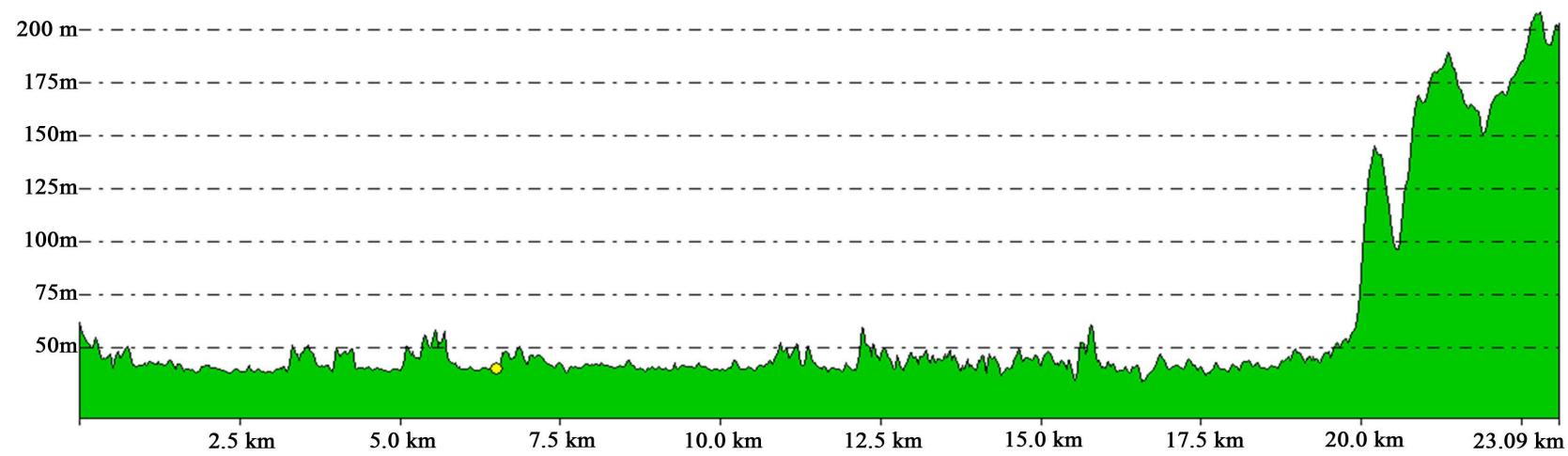

Figure 2. Cross section for Mellawy center by using GIS software including El-Ashmonein archaeological site in yellow point. 
meeting, education, etc., and to achieve its purposes it was necessary to have walls of carrier or coverslip to the roofs and pillars and pillars and jealousy. Limestone or granite was used by all peoples throughout the ages. He said that the pillars have origins dating back to the early ages when the early inhabitants of the Nile supported their plant huts and their bishop's boughs with branches of trees or branches and trees. The researcher discussed the development of pillars in the Pharaonic era and their forms, Greek, Roman, Coptic and Islamic columns [5]. S. R. Snape (1989) this book about one of the most important monuments at El-Ashmounein called the temple of Domitian, in this book the author showed the map of central area of Hermopolis Magna by the British museum expedition survey, 1980-1981 (R. Andrews), and also the map of Hermopolis Magna, October 1800 (E. Jomard) [6]. Shaw, I. and Jameson, R. (Eds.) (1999) this dictionary told us that (el-Ashmunein; anc. Khmun) Egyptian site located close to the modern town of Mallawy, which was the cult-center of the god Thoth and capital of the 15th Upper Egyptian province. It was subject to extensive plundering in the early Islamic period, but there are still many remains of temples dating to the Middle and New Kingdoms, including a pylon (ceremonial gateway) constructed by Ramesses II (c.1290-1224 BC). The latter contained stone blocks quarried from the abandoned temples at the nearby site of EL-AMARNA (c.1353-1335 BC). There is also a comparatively well-preserved COPTIC basilica built entirely in a Greek architectural style and reusing stone blocks from a Ptolemaic temple [7]. G. Roeder: Hermopolis 1929-39 (Hildesheim, 1959); J.D. Cooney: Amarna reliefs from Hermopolis in American collections (Brooklyn, 1965); G. Roeder and R. Hanke: Amarna-reliefs aus Hermopolis, 2 vols (Hildesheim, 1969-78); A. J. Spencer: Excavations at el-Ashmunein, 4 vols (London, 1983-93). Maehler, H (2012) He said that Hermopolis Magna, whose modern name El-Ashmunein is derived through Coptic Shmûn from the original Kmunu ("City of the Eight" $s c$. gods), is situated on the west bank of the Nile some $40 \mathrm{~km}$ south of el-Minia and $7 \mathrm{~km}$ north of Mellawi and discussed Greek history and roman history [8]. S. L. Lippert (2012) explained Designation of a demotic manuscript (third century bce) written on the recto of a papyrus found at Hermupolis Magna (Ashmunein) in Upper Egypt in 1938, now in the Egyptian Museum at Cairo (P. Cairo JE $89127-89130+89137-89143)$; on the verso is a mathematical text [9]. Basem Samir Elsharqwi (2005) in his book showed that Minya Governorate is one of the most important governorates of Egypt for its average location and extension along the Nile River about $135 \mathrm{~km}$ and the average width of about $18 \mathrm{~km}$, and because it contains many beautiful sites called the bride of the Upper and Nile, and showed the archeological sites in Minya Governorate generally and the old buildings, houses and palaces [10]. Abdelhaim Nour Eldin (2007) he showed the importance of El Minya and illustrated a lot of sites such as sultan corner, Elkom Alhmar, Beni Hassan, Establ Antar, small Establ, Sharouna and so on [11]. Ezaa Qadous (2010) illustrated the monuments which belongs to Greco roman era in upper, middle and Lower Egypt, and told us about El-Ashmounein site and its monuments, so he said 
El-Ashmounien ruins are located near the current city of Mallawi and are about $12 \mathrm{~km}$ from Mallawi. As for the discovery, it appeared when the Antiquities Authority to explore the monuments of this area in 1938 to search for the market for the Roman city [12]. Martin Bommas, Juliette Harrisson (2014) they referred that the construction of great basilica and the south church show that Christian leaders of the fifth century were actively engaged wuth the city's pagan monumental landscape and reshaping it in creative ways [13]. A. J. B. Wace, A. H. S. Megaw and others (1959) said that the basilica's remains were discovered in 1942 by M. Kamal. In the following years an expedition of the University in Alexandria cleared the whole monument [14] [15]. Capuani (2002) came out with a new typological classification. He splits the Churches of Egypt into two geographical zones. The first is the Mediterranean coast and Delta, where the church style is mostly affected by the Byzantine architecture. The second is the Nile Valley, where local cultural impact on the Church designs in his point of view is recognized. He further analyzes church designs chronologically as Bishop Samuel and Badie Habib did, but focused on plan design itself and not ceiling design [16].

\section{Destruction of Basilica Church}

No early remains had been found there, but this is probably the result of the destruction that happened to the city. The site is in abroad and rich area of the Nile valley. It is now very badly ruined, with small parts of temples standing above the general rubble. Only the roman period agora with its early Christian basilica is at all well preserved, giving evidence of the great prosperity of the town in late monuments as shown in Figure 3 general current state of the archaeological site of El-Ashmonein and the basilica church.

Different reasons for the destruction of the archaeological site at El-Ashmounein according to Spencer [17]:

- During the roman period the character of the sacred areas of El-Ashmounein was seriously changed by the redevelopment of the site as Hellenistic city.

- Many new public buildings and temples of classical style were constructed in and around the temple complex, especially along Antinoe street and the Dromos of Hermes.

- The extensive alteration to the central city inevitably swept away some of the older pharaonic structure where a good portion of the new kingdom temple of Thoth had already gone in the Potlemaic period to clear a path for Dromos.
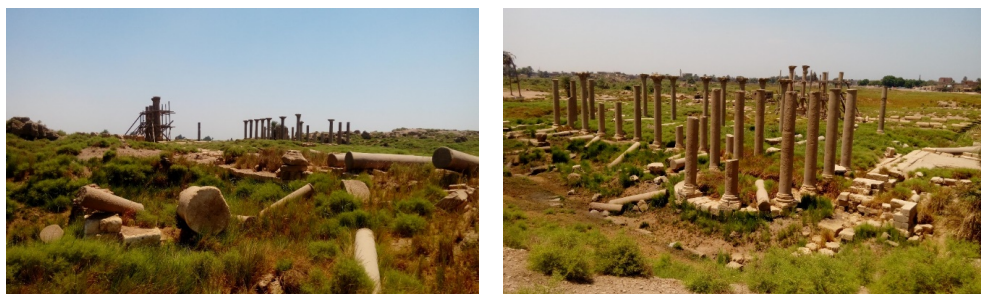

Figure 3. The current state of preservation of the archaeological site of El-Ashmounein. 
- The destruction and overbuilding of the sacred areas began in the fourth century $\mathrm{AD}$ because of the collapse of old religion and the increasing adoption of Christianity.

- Throughout the fifth and sixth century the enclosure of Thoth was rapidly overlaid by deep deposits of rubbish and fill, but few built structures except for small squatters' huts.

- Subsequent rubbish dumping from the seventh century AD until well into the Islamic period is marked by discarded ceramics of this age in pits sunk into the fifth century fill.

- During the fifth century the rise in ground level on the old temple site was very rapid so in some places reaching more than three meters above the temple floor level caused many problems for the columns where the columns moved and collapsed upside down as shown in Figure 4, so that the flash flooding the main reason for the destruction of the site.

- Small building formed of baked bricks and reused stones from the temples had been founded above the fifth century fill.

- Small building formed of baked bricks and reused stones from the temples had been constructed together with the extensive pitting of the ground resulted in the fill being repeatedly distributed over a long period.

- The temples lay exposed until the fifth century AD made them vulnerable to quarrying, either for building stone or as a source of limestone for lime burning.

- A considerable quantity of stone used for the basilica church and other blocks have been found reused in a small building above the temple site itself.

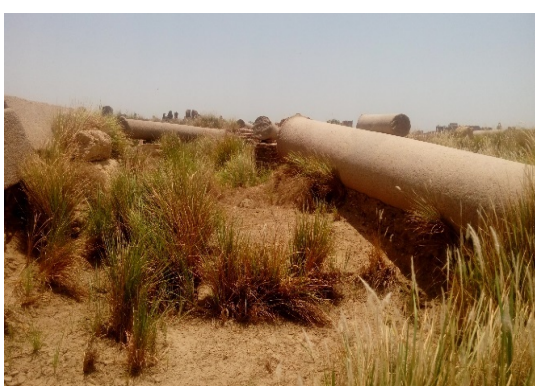

(a)

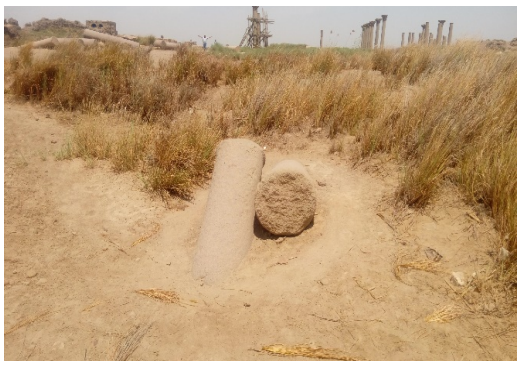

(c)

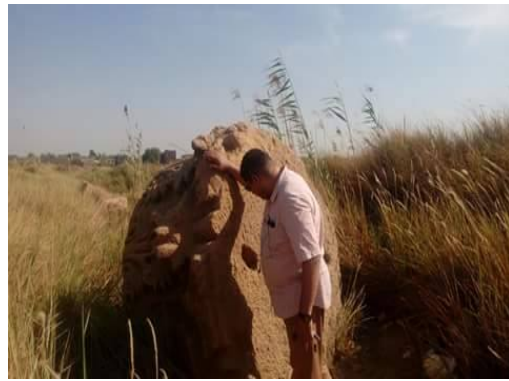

(b)

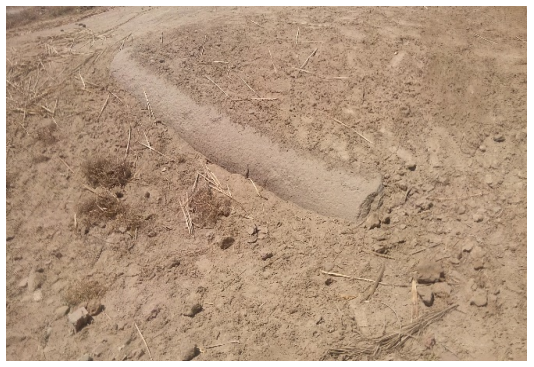

(d)

Figure 4. The destructed granite columns as a result of ancient flash flooding and earthquakes activities. 
- Prominent architectural features comprising large masses of stone masonry such as pylons and large gateways, would have been noted as a source of limestone to feed the lime kiln, three lime kilns were founded by the German team, sited immediately north of pylon in order to exploit it for limestone.

- Other monuments were collected and brought to the spot of burning, including statues of the Ramesses II and Nectanebo I and the great stela of the latter king.

- In 1984 the British museum worked in the site and found out another large kiln used for quicklime preparation.

- Quarrying activities was evident in all sites and the reason for the poor state of preservation of the pharaonic and later temples.

- Also, one of the most important factors of destruction of the basilica church and the site generally was the anthropogenic factors so the columns was used as a building material for the modern houses and other buildings.

\section{Architectural and Structural Description of Basilica Church}

At the beginning of $4^{\text {th }}$ century $\mathrm{AD}$, Christianity finally overcame the former pagan religions in Egypt. Therefore, from that time onward, a sustained architectural effort aimed at the building of Christian churches. During the Christian period, these churches represent the only type of edifice to be constructed in monumental proportions. The typology of Egyptian churches varied considerably depending on their location (for example, those built on the Mediterranean coast as opposed to the Nile Valley), whether they were built in urban or rural settings and whether or not they were connected to a monastery. However, certain generalities may be defined, and as the following is the style of basilica church called (Basilica with Transept), between the fifth and sixth centuries AD, we find, only in urban settings, the basilica with transept. This type of church was mainly located in the delta or middle Egypt regions, and was considered to be an import of architectural styles from Constantinople and the Byzantine world. The rather rare typology consists of a basilica with a nave separated from the side aisles by two ranks of columns which in general also encircle the transept. A common trait of the transept was that its north and south ends are either rectilinear or semi-circular. Examples of this type of church include [18]: Al-Hawariya (Marea) - the 6th Century, Sanctuary of St. Menas-the 5th and the 6th Centuries and Hermopolis (El-Ashmonein) - the 5th Century.

The predominant type of Christian architecture in Egypt is Basilican; it has been fashion to regard as adopted from the secular roman basilica by the early Christians, according to the architect Scott, who shows the reason for assigning an earlier and independent origin of this building. According to his theory the germ of the Christian basilica was a simple oblong aisles room divided by a cross arch, beyond which lay an alteration detached from the wall. This germ was developed by addition of side aisles returned across the entrance end, over these upper aisles were next constructed and transepts added with small oratories or 
chapels in various parts of building. On the other hand, the secular basilica is shown to have begun with a colonnade enclosing an open area, to have begun roofed in, to have lost the colonnades, and to have passed into a lofty hall covered with a brick vaulting. But Butler has another idea that it is of course clear that the two separated developments at one point closely coincided and the resemblance at the first accidental became in later times conscious and designed, but the secular basilicas of the fourth century are very different from the Christian churches of the epoch which resemble rather the pagan basilicas of three centuries earlier [19].

The great cathedral was a big basilica building with side galleries and built in the center of the city. It has a colonnaded transept with exedrae at both ends. The church building with atrium and adjacent rooms formed an independent complex set in the very center of the ancient town. The basilica church complex consists of the following [20]:

- The church is a big basilica with side galleries.

- The structural system is a granite column of $8.5 \mathrm{~m}$ height and $88 \mathrm{~mm}$ diameter resting on a limestone isolated footings and limestone slaps and beams.

- Its length is 55 meters, span of nave is $14.7 \mathrm{~m}$ and depth of aisles is $5.6 \mathrm{~m}$.

- The columnated transept has exedrae at both ends. These features make the basilica is one of the most important examples of early Christian architecture development.

- At the eastend there is a great apse of width equal to the nave span.

- The western part of the church was ended by esonarthex, which later completed by narthex.

- On its north and south sides there were unsymmetrically situated staircases which led to the side galleries.

- It is supposed that its ceiling is from wood. Presumably the basilica was 22 meters high.

- There were two entrances leading to the basilica, the main entrance from spacious atrium was situated on the western end of the church. The other one was the side entrance of situated on the north leading from the Antione Street through the four-column portico (the tetrastyle).

- The baptistery tank was situated on the north east corner of the church complex (Figure 5).

\section{Materials and Methods}

Several laboratory examination and analyses were carried out to identify the nature of the granite and limestone used to build the basilica church. About 40 samples represent the construction materials (granite and limestone) were collected from the fallen fragments. Nine thin sections were examined using polarizing light microscopy to identify the petrographic characteristics of these construction materials. XRD and XRF analyses were performed to identify the components and ratios of the elements in the installation granite and limestone; 

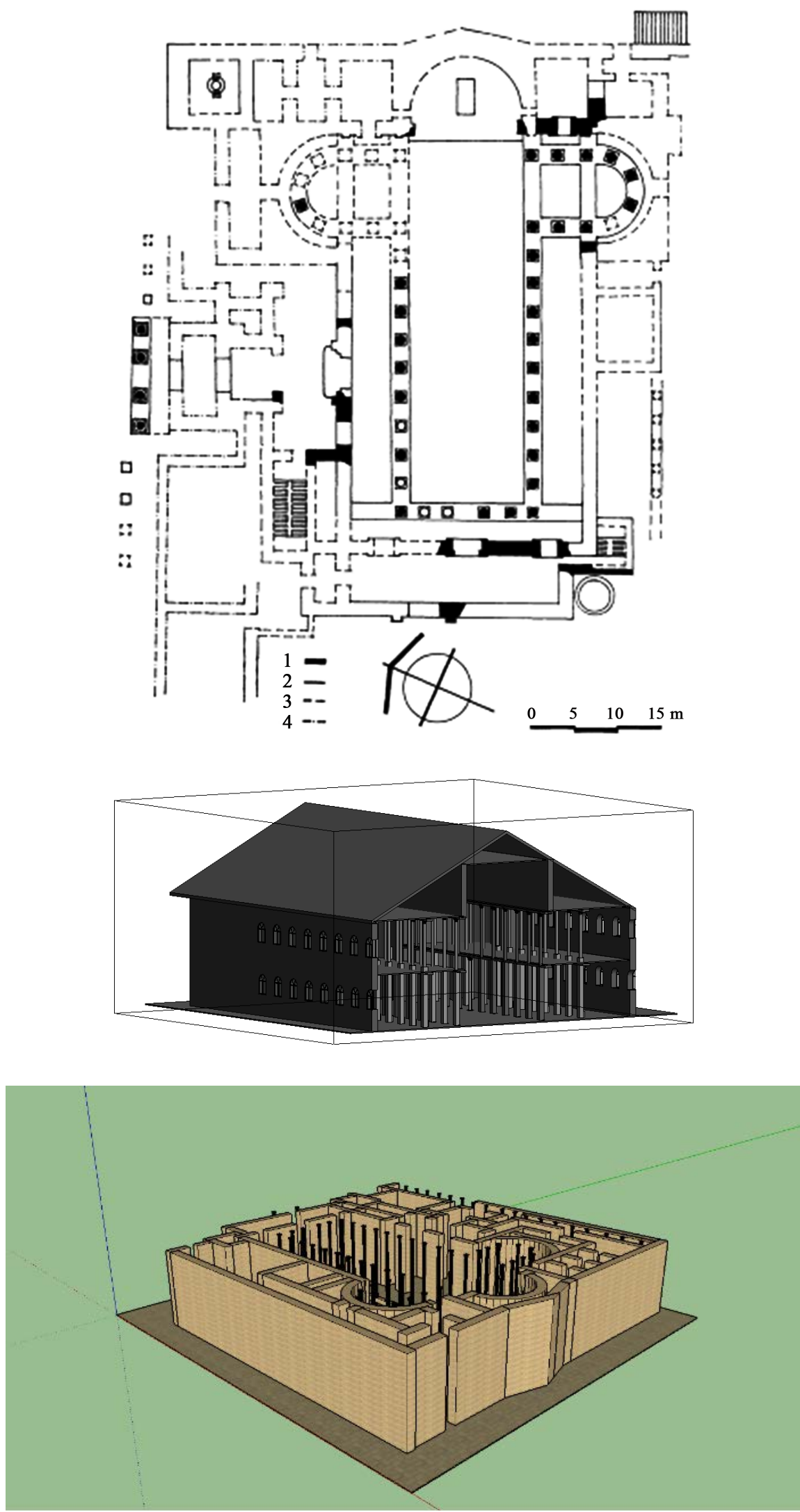

Figure 5. Modelling of the basilica church with the plan of the reconstruction of basilica church at Al-Ashmounein archaeological site. 
along with the SEM equipped with EDX for microstructure examination and micro chemical analysis. XRD diffraction patterns of both the studied bricks and the mortar samples are gained through $\mathrm{Cu} \mathrm{K}$ radiation. The scanning speed is $2 \theta$ $=1 \mathrm{degree} / \mathrm{min}$. at constant voltage $40 \mathrm{kV}$, and $30 \mathrm{~m} \mathrm{~A}$ using PW $1480 \mathrm{X}$-ray diffraction. The identification of the Constituents has been achieved using the ASTM Cards through determining the d-values of the different atomic planes and their relative intensities. Major elements (wt\%) of the studied mortar samples have been performed using X-ray fluorescence spectrometry (XRF) on a modern Wavelength Dispersive Spectrometer (Axios, WD-XRF Spectrometer, PANalytical, 2005, Netherlands). The chemical analyses were carried out adopting the ASTM specifications (ASTM C114-00 (ASTM C114-15). Scanning Electron Microscope (SEM) images were performed on JXA 840A electron probe micro analyzer, Japan, as well as the Raman spectroscopy analysis.

The physical and the mechanical characteristics of the studied construction materials (granite and limestone) were achieved. Morphology and color analysis were identified by visual observation. Forty-three cylindrical specimens have been prepared from the granite and limestone to delineate the physical and mechanical properties. Specific gravity, unit weight, water absorption, porosity and degree of saturation are the physical aspects determined. While, the mechanical characterization included the determination of the uniaxial compressive strength, flexural strength test, elastic static modulus of elasticity and Brazilian splitting tensile strength, as well as the Non-Destructive Ultrasonic Pulse Testing to the wave velocity through the granite and limestone specimens, the dynamic Young's modulus and shear modulus. The study finalized with some non-destructive evaluation methods like Schmidt hammer test and Seismic analyzer test (P and S waves). Many correlation and formulas have been established between the different parameters.

\subsection{The Analytical Study}

The analysis process has been carried out upon different kind of construction materials for columns of basilica church and Ramses II/Nero temple. The construction materials are Limestone and granite where limestone brought from Minia formation and Granite from Aswan. The methods which used for analysis are (XRD) X-Ray diffraction, (XRF) X-Ray florescence, (RS) Raman Spectroscopy.

\section{- Analysis of limestone and granite with XRD}

Limestone of the free-standing stone columns especially for crowns, bases analyzed by using XRD identifies the chemical composition of sample, the samples analyzed by central laboratories sector (the Egyptian minerals resources). There are many studies have been carried out on Minia formation as a source of limestone used in columns. For example, M. A. W. Gaber (2017) [21] showed his research XRD analysis for Minia Limestone and his results said that in Samlut area the $\mathrm{XRD}$ indicates the calcite mineral is the most predominant minerals of 
limestone ore (major mineral) with average ratio $99.5 \% 7$ and Beni Khalid limestones are composed mainly of calcite, the $\mathrm{XRD}$ results complies with chemical composition analysis that the $\mathrm{CaCO}_{3}$ is $99.30 \%$. Chemical analysis carried out for samples collected from deteriorated fallen part of limestone column and the results indicates that the main composition is calcite mineral as shown in Table 1 and it is so important to say that the results is matching with (M. A. W. Gaber) results.

There are also many studies have been carried out such as (M. A. El-Gohary, 2011) [22] demonstrated the chemical composition of granite of Aswan by using XRD. The result of "M. A. El-Gohary" research on weathered granite taken from unfinished obelisk displayed that the components of red spots consist of different phases of minerals which can be distinguished as follows: Assembly of microcrystal of Sanidine $\left[(\mathrm{K}, \mathrm{Na}) \mathrm{AlSi}_{3} \mathrm{O}_{8}\right]$, Anorthite $\left[\mathrm{CaAl}_{2} \mathrm{Si}_{2} \mathrm{O}_{8}\right]$, Quartz $\left[\mathrm{SiO}_{2}\right]$, Oligioclase $\left[(\mathrm{Na}, \mathrm{Ca})(\mathrm{Si}, \mathrm{Al})_{4} \mathrm{O}_{8}\right]$ and Biotite $\left[\mathrm{K}\left(\mathrm{Mg}, \mathrm{Fe}^{++}\right)_{3} \mathrm{AlSi}_{3} \cdot \mathrm{O}_{10}(\mathrm{OH})_{2}\right]$, as essential minerals of granite especially in semi-affected areas. Other major phases are disseminated in this microcrystalline matrix as weathering and salty products especially in highly affected areas such as Montmorillonite [( $\mathrm{Al}$, $\mathrm{Mg})_{8}\left(\mathrm{Si}_{4} \mathrm{O}_{10}\right)_{4}(\mathrm{OH})_{8} \cdot 12 \mathrm{H}_{2} \mathrm{O}$ ], Illite [K-Na-Mg-Fe-Al-Si-OH $\mathrm{H}_{2} \mathrm{O}$ ], in addition to other minor phases as Chlorite $\left[(\mathrm{Mg}, \mathrm{Fe})_{3}\left(\mathrm{Si}, \mathrm{Al}_{4} \mathrm{O}_{10}(\mathrm{OH})_{2} \cdot(\mathrm{Mg}, \mathrm{Fe})_{3}(\mathrm{OH})_{6}\right]\right.$, Tosudite $\left[\mathrm{Na}_{0 \cdot 3} \mathrm{Al}_{6}(\mathrm{Si}, \mathrm{Al})_{8} \mathrm{O}_{20}(\mathrm{OH})_{10} \cdot 4 \mathrm{H}_{2} \mathrm{O}\right]$, and Gypsum [CaSO $\mathrm{C}_{4} \cdot 2 \mathrm{H}_{2} \mathrm{O}$ ], Hematite $\left[\mathrm{Fe}_{2} \mathrm{O}_{3}\right]$ and two of these crystalline phases. The archaeological samples of granite analysed by XRD andthe results are the following components; Quartz $\mathrm{SiO}_{2}$, Albite $\mathrm{Na}\left(\mathrm{Si}_{3} \mathrm{Al}\right) \mathrm{O}_{8}$, Microcline $\mathrm{K}_{0.92} \mathrm{Na}_{0.08} \mathrm{Al}_{0.99} \mathrm{Si}_{3.01} \mathrm{O}_{8}$ and Muscovite-2M1, $\mathrm{KAl}_{2}(\mathrm{Si}, \mathrm{Al})_{4} \mathrm{O}_{10}(\mathrm{OH})_{2}$ as shown in Table 2. Also, two representative samples prepared from Aswan quarry in missing obelisk area and analyzed by XRD as summarized in Table 3 and Table 4.

Table 1. Chemical compounds of limestone from columns by XED.

\begin{tabular}{ccc}
\hline Ref. Code & Mineral Name & Chemical Formula \\
\hline $01-072-4582$ & Calcite & $\mathrm{Ca}\left(\mathrm{CO}_{3}\right)$ \\
\hline
\end{tabular}

Table 2. Results of XRD analysis for archaeological granite taken from weathered fallen granite.

\begin{tabular}{cc}
\hline Quartz & $\mathrm{SiO}_{2}$ \\
Albite & $\mathrm{Na}\left(\mathrm{Si}_{3} \mathrm{Al} \mathrm{O}_{8}\right.$ \\
Microcline & $\mathrm{K}_{0.92} \mathrm{Na}_{0.08} \mathrm{Al}_{0.99} \mathrm{Si}_{3.01} \mathrm{O}_{8}$ \\
Muscovite-2M1 & $\mathrm{KAl}_{2}\left(\mathrm{Si}, \mathrm{Al}_{4} \mathrm{O}_{10}(\mathrm{OH})_{2}\right.$ \\
\hline
\end{tabular}

Table 3. Results of XRD analysis for Quarry Aswan of granite S1.

\begin{tabular}{ccc}
\hline Ref. Code & Mineral Name & Chemical Formula \\
\hline $01-089-6427$ & Albite (heat-treated) & $\mathrm{Na}_{\left(\mathrm{AlSi}_{3} \mathrm{O}_{8}\right)}$ \\
$01-074-3485$ & Quartz, syn & $\mathrm{SiO}_{2}$ \\
$01-089-5370$ & Actinolite & $(\mathrm{Fe}, \mathrm{Mg}, \mathrm{Ca}, \mathrm{Na}, \mathrm{Mn})_{7} \mathrm{Si}_{8} \mathrm{O}_{22}(\mathrm{OH})_{1.9} \mathrm{Fe}_{0.04}$ \\
$01-072-1114$ & Microcline & $\mathrm{KAlSi}_{3} \mathrm{O}_{8}$ \\
\hline
\end{tabular}


Table 4. Results of XRD analysis for quarry Aswan of granite S1.

\begin{tabular}{ccc}
\hline Ref. Code & Mineral Name & Chemical Formula \\
\hline $01-072-1246$ & Albite & $\mathrm{Na}\left(\mathrm{AlSi}_{3} \mathrm{O}_{8}\right)$ \\
$01-074-3485$ & Quartz, syn & $\mathrm{SiO}_{2}$ \\
$00-058-2015$ & Illite-2M2 & $\left(\mathrm{K}, \mathrm{H}_{30}\right) \mathrm{Al}_{2}\left(\mathrm{Si}_{3} \mathrm{Al}\right) \mathrm{O}_{10}(\mathrm{OH})_{2} \cdot \mathrm{xH}_{2} \mathrm{O}$ \\
$01-076-0830$ & Microline & $\mathrm{K}_{0.92} \mathrm{Na}_{0.08} \mathrm{Al}_{0.99} \mathrm{Si}_{3.01} \mathrm{O}_{8}$ \\
\hline
\end{tabular}

\section{- Elemental analysis of limestone and granite with XRF}

$\mathrm{XRF}$ is so important to identify the exact minor and major elements for limestone sample which collected from deteriorated fallen limestone. Also, there are many studies studied the Minia formation and made chemical analysis by using XRF for different areas in Minia as (Gaber M.A. Wahab, 2017) told us in his paper and The XRF analysis of collected limestone revealed that the major element is $\mathrm{CaO} 55.70$; accordingly, the $\mathrm{CaCo}_{3}$ is $99.65 \%$ and the archaeological sample results as shown in Table 5.

For granite, there are many studies carried out using XRF for granite from unfinished obelisk (M. A. El-Gohary, 2011) [22]. He made chemical analysis for six samples from Aswan granite to know the majority elements of granite and cause of degradation. XRF carried out on archaeological samples comparing to the previous study on quarry. Table 6 shows the result of XRF for archaeological sample from weathered fallen parts of granite.

\section{- Analysis of limestone and granite with Raman spectroscopy}

The aim of this instrument is to identify the material and its components as shown in Figure 6 for limestone and Figure 7 the spectrum of archaeological granite sample and Figure 8 the quarry sample of granite from Aswan. The Raman spectroscopy which used in analysis is at BeniSuef University laboratory, VERTEX 70, Bruker Optics, Germany (Figure 9).

\section{- Analysis of mortar}

\section{1) Analysis of mortar with XRD}

XRD has been used to identify the components of the archaeological mortar which had been used in archaeological building. The components of mortar are gypsum, calcite, quartz and basanite as summarized in Table 7 shows the results of XRD pattern for archaeological material.

\section{2) Analysis of mortar with XRF}

This instrument has been used to identify the elements of archaeological mortar in El-Ashmounein archaeological site as shown in Table 8 the results of XRF for archaeological mortar.

\subsection{Diagnosis and Examination of the Construction Materials}

Investigation or examination of building materials is so important to assess the weathering state of the building materials and to evaluate the factors and mechanism of weathering in addition to that the current state of preservation the columns. The investigation and examination have been done by using the 


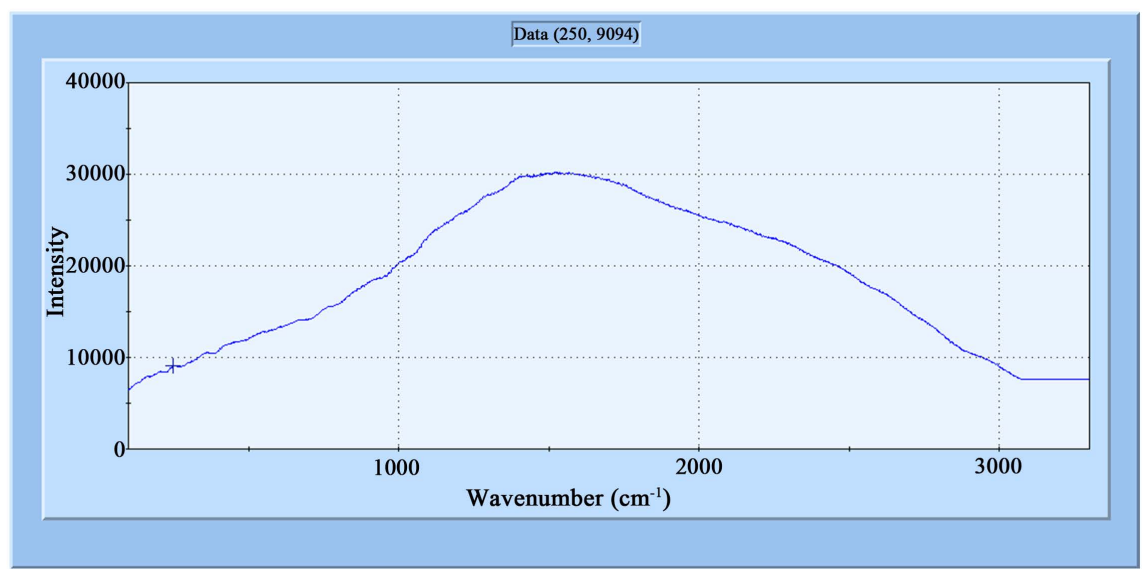

Figure 6. The spectrum of limestone.

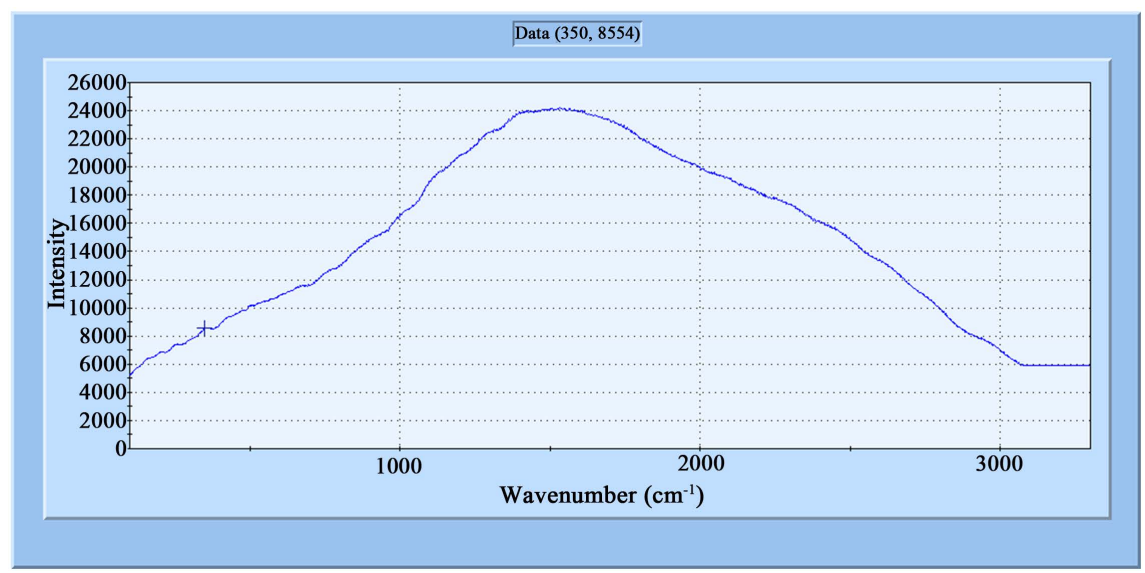

Figure 7. The spectrum of archaeological granite sample.

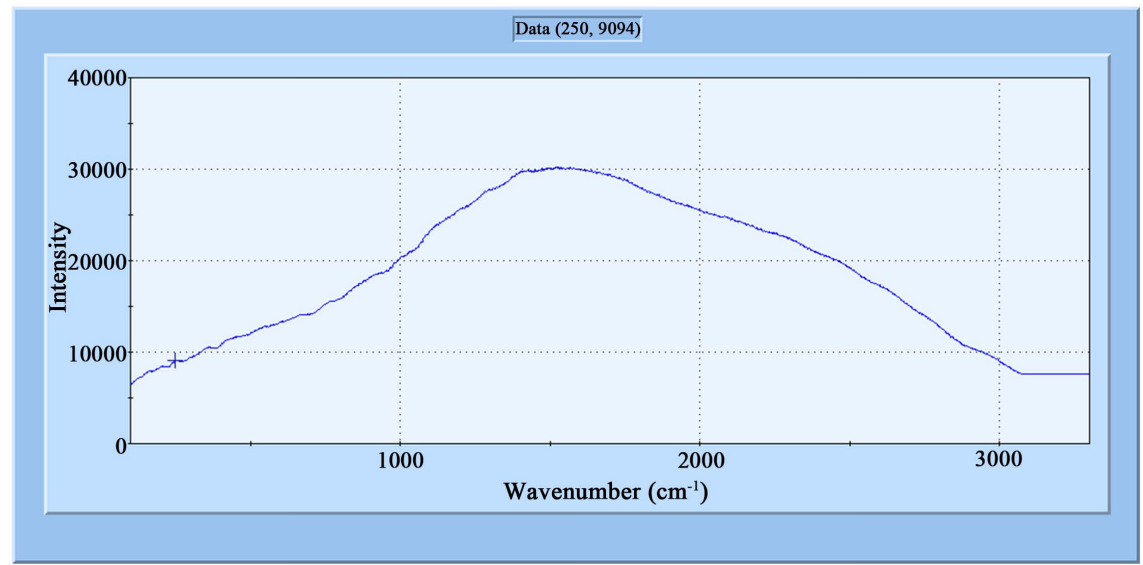

Figure 8. The quarry sample of granite from Aswan.

Table 5. The elemental analysis results by using XRF for a weathered fallen limestone sample.

\begin{tabular}{llllllllllllllllllllll} 
C.N. & D.N. & $\mathrm{SiO}_{2}$ & $\mathrm{TiO}_{2}$ & $\mathrm{Al}_{2} \mathrm{O}_{3}$ & $\mathrm{Fe}_{2} \mathrm{O}_{3}$ & $\mathrm{MnO}$ & $\mathrm{MgO}$ & $\mathrm{CaO}$ & $\mathrm{Na}_{2} \mathrm{O}$ & $\mathrm{K}_{2} \mathrm{O}$ & $\mathrm{P}_{2} \mathrm{O}_{5}$ & $\mathrm{Cl}$ & $\mathrm{SO}_{3}$ & L.O.I \\
\hline 3695 & 1 & 0.73 & $<0.01$ & 0.02 & 0.02 & $<0.01$ & 0.04 & 55.40 & $<0.01$ & 0.01 & $<0.01$ & $<0.01$ & 0.01 & 43.50
\end{tabular}




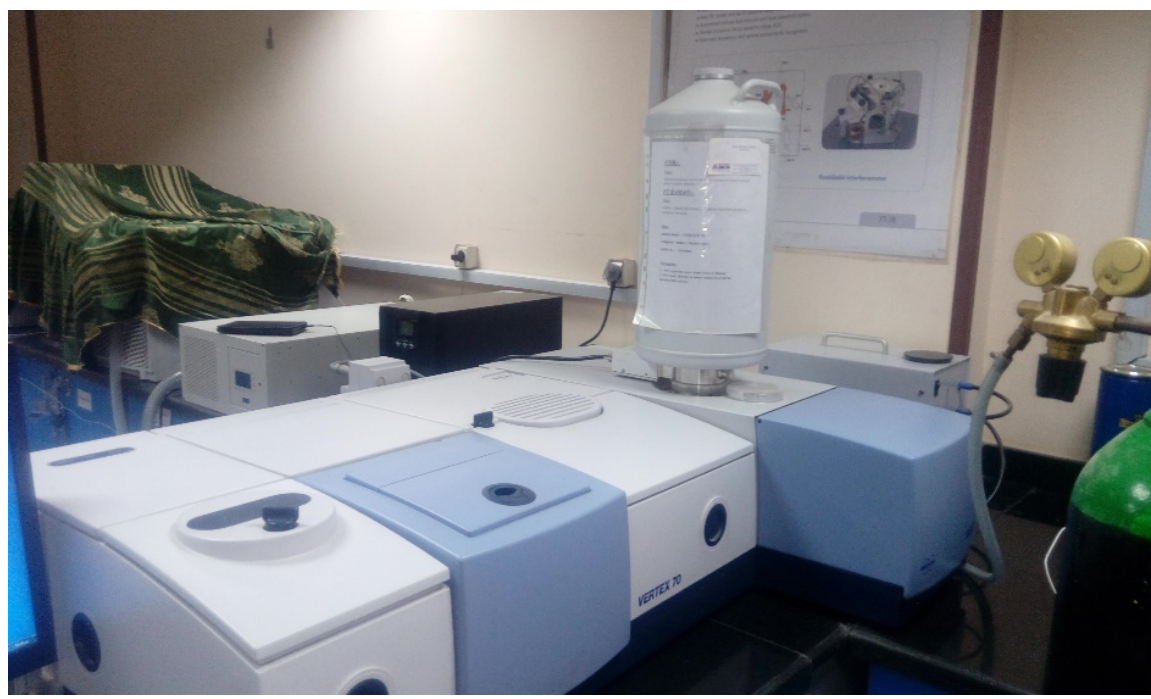

Figure 9. FT Raman Spectroscopy which have been used to identify the presence of certain functional groups in inorganic molecule.

Table 6. Result of XRF for archaeological sample from weathered fallen parts of granite.

\begin{tabular}{ccccccccccccccc} 
C.N. & D.N. & $\mathrm{SiO}_{2}$ & $\mathrm{TiO}_{2}$ & $\mathrm{Al}_{2} \mathrm{O}_{3}$ & $\mathrm{Fe}_{2} \mathrm{O}_{3}$ & $\mathrm{MnO}$ & $\mathrm{MgO}$ & $\mathrm{CaO}$ & $\mathrm{Na}_{2} \mathrm{O}$ & $\mathrm{K}_{2} \mathrm{O}$ & $\mathrm{P}_{2} \mathrm{O}_{5}$ & $\mathrm{Cl}$ & $\mathrm{SO}_{3}$ & L.O.I \\
\hline 3696 & 2 & 71.60 & 0.54 & 12.50 & 3.48 & 0.04 & 0.01 & 1.30 & 2.83 & 6.70 & 0.10 & $\mathrm{ND}$ & 0.01 & 0.60
\end{tabular}

Table 7. The results of XRD pattern for archaeological material.

\begin{tabular}{cccc}
\hline Ref. Code & Mineral Name & Chemical Formula & Semi Quant [\%] \\
\hline $00-006-0047$ & Gypsum & $\mathrm{CaSO}_{4} \cdot 2 \mathrm{H}_{2} \mathrm{O}$ & 69 \\
$01-089-1305$ & Calcite, magnesium & $\left(\mathrm{Mg}_{0.06} \mathrm{Ca}_{0.94}\right)\left(\mathrm{CO}_{3}\right)$ & 20 \\
$00-033-0310$ & Bassanite & $\mathrm{CaSO}_{4} \cdot 0.5 \mathrm{H}_{2} \mathrm{O}$ & 4 \\
$01-074-3485$ & Quartz, & $\mathrm{SiO}_{2}$ & 7 \\
\hline
\end{tabular}

Table 8. The results of XRF for archaeological mortar.

\begin{tabular}{lcccccccccccccc}
\hline C.N. & D.N. & $\mathrm{SiO}_{2}$ & $\mathrm{TiO}_{2}$ & $\mathrm{Al}_{2} \mathrm{O}_{3}$ & $\mathrm{Fe}_{2} \mathrm{O}_{3}$ & $\mathrm{MnO}$ & $\mathrm{MgO}$ & $\mathrm{CaO}$ & $\mathrm{Na}_{2} \mathrm{O}$ & $\mathrm{K}_{2} \mathrm{O}$ & $\mathrm{P}_{2} \mathrm{O}_{5}$ & $\mathrm{Cl}$ & $\mathrm{SO}_{3}$ & L.O.I \\
\hline 3698 & B & 1.82 & 0.03 & 0.08 & 0.23 & 0.01 & 1.13 & 22.31 & 12.53 & 2.04 & 0.01 & 13.61 & 30.05 & 15.9
\end{tabular}

following techniques; polarizing microscope (PLM), Scanning electron microscope (SEM), and digital microscope. The investigation and examination had been used for archaeological granite, limestone and mortar.

\section{- Investigation of limestone and granite with polarizing microscope (PLM/C.N)}

Polarized light microscopy provides us a unique window into the internal structure of crystals and at the same time is aesthetically pleasing due to the colors and shapes of the crystals. The use of PLM as a tool for crystallography extends back at least 200 years. For many of those years, it was the prime tool for examining the crystal properties of minerals and inorganic chemicals, as well as organics [23]. The study revealed the samples are represented and described as the following: 


\begin{tabular}{|c|c|}
\hline $\begin{array}{c}\text { Construction } \\
\text { material }\end{array}$ & Limestone \\
\hline Rock name & Fossiliferous limestone (Biomicrite) \\
\hline Rock type & Organic, sedimentary rock \\
\hline Texture & $\begin{array}{l}\text { The rock is very fine to fine-grained. Microfossils } \\
\text { are scattered in very fine-grained of calcite } \\
\text { (micrite matrix) and filled by recrystallized } \\
\text { carbonate (sparitic calcite) and some } \\
\text { microfossils filled by micritic calcite }\end{array}$ \\
\hline $\begin{array}{c}\text { Mineral } \\
\text { composition }\end{array}$ & $\begin{array}{l}\text { The rock is very fine to fine-grained and } \\
\text { composed mainly of carbonates (mainly calcite) } \\
\text { as the essential component associated with minor } \\
\text { amounts of iron oxides and opaques and rare } \\
\text { amounts of phosphate minerals, microcrystalline } \\
\text { quartz and clay minerals. Carbonates } \\
\text { (mainly calcite) represent the matrix of the rock } \\
\text { and occur as very fine-grained, anhedral crystals } \\
\text { interlocking to each other. Significant number of } \\
\text { microfossils and shell fragments in different } \\
\text { shapes and sizes are observed scattered in the } \\
\text { matrix of the rock and filled by recrystallized } \\
\text { carbonates (sparite) and some microfossils filled } \\
\text { by micrite. Opaque minerals occur as very fine } \\
\text { to fine-grained aggregates and scattered } \\
\text { commonly at the boundaries of the microfossils. } \\
\text { Phosphate minerals (collophane) occur in rare } \\
\text { amount and scattered in carbonate matrix. } \\
\text { Microcrystalline quartz occurs in rare amount } \\
\text { and observed distributed in the rock. } \\
\text { Few irregular pores are observed in the rock as } \\
\text { shown in Figure } 10 \text { the samples investigated } \\
\text { under polarizing microscope Crossed Nicole } \\
\text { and the samples investigated under } \\
\text { polarizing microscope (PLM) }\end{array}$ \\
\hline
\end{tabular}

Images Figure 10

Recrystallization of primary carbonate (calcite) detected in the microfossils and shell fragments to form a coarser grained calcite. Some pore spaces are detected in the sample due to dissolution of the original constituents such as fossils shell as shown in Figure 11.
Altered perthitic granite

plutonic, felsic igneous rock

The rock is medium to coarse-grained showing granular, hypidiomorphic, perthitic and piokilitic textures.

The rock is composed mainly of alkali feldspar (microcline \& orthoclase perthite), quartz, plagioclase, biotite and hornblende together with accessory of titanite, zircon, apatite and opaque minerals as shown in Figure 12. Secondary minerals are represented by sericite, carbonates, clay minerals, chlorite and iron oxides. Alkali feldspar (microcline \& orthoclase perthite) is the most abundant constituent of the whole rock. It is coarse-grained, generally anhedral crystals and slightly altered and turbid with clay minerals. Some crystals of feldspars are deformed and corroded due to mild deformation effect. Quartz is essential mineral constituent occurs as fine to coarse-grained, anhedral crystals and filling the interstitial spaces between feldspar crystals. It shows stretched crystals, corroded, granulated, curved boundaries and deformed due to deformation effect. Plagioclase is medium to coarse-grained, subhedral platy in form and shows distinct lamellar twinning and partially altered to sericite and carbonate minerals. It presents also as irregular lamellae, thin films and fine inclusions intergrowths in microcline \& orthoclase perthite showing perthitic texture.

It is also somewhat deformed and shows curved lamella. Biotite occurs as fine to medium-grained tabular, flaky crystals at the interstices of feldspars and quartz. It is strongly pleochroic; and partially to highly altered to chlorite with liberation of iron oxides at its cleavage planes and borders. Locally radioactive halos are noticed within biotite crystals (probably due to the presence of radioactive zircon). Hornblende occurs as fine to medium-grained tabular, prismatic crystals at the interstices of feldspars and quartz.

It is commonly associated with biotite; and partially to highly altered to chlorite with liberation of iron oxides at its cleavage planes and borders. Titanite is very fine to fine-grained; subhedral to euhedral rhombic and/or acute crystals, mainly associated with altered biotite and hornblende (most probably as alteration product). Zircon is very rare, extremely fine-grained, euhedral in form and generally noticed in association with biotite and hornblende.

Figure 12

The rock is affected by alteration and deformation over original constituents. Alkali and plagioclase feldspars are partially altered to sericite, carbonates and clay minerals. Mafic minerals (biotite and hornblende) are partially to highly altered to chlorite with liberation of iron oxides at its cleavage planes and borders. The rock affected by deformation and granulation over essential constituents especially in quartz and mafic minerals as shown in Figure 13. 

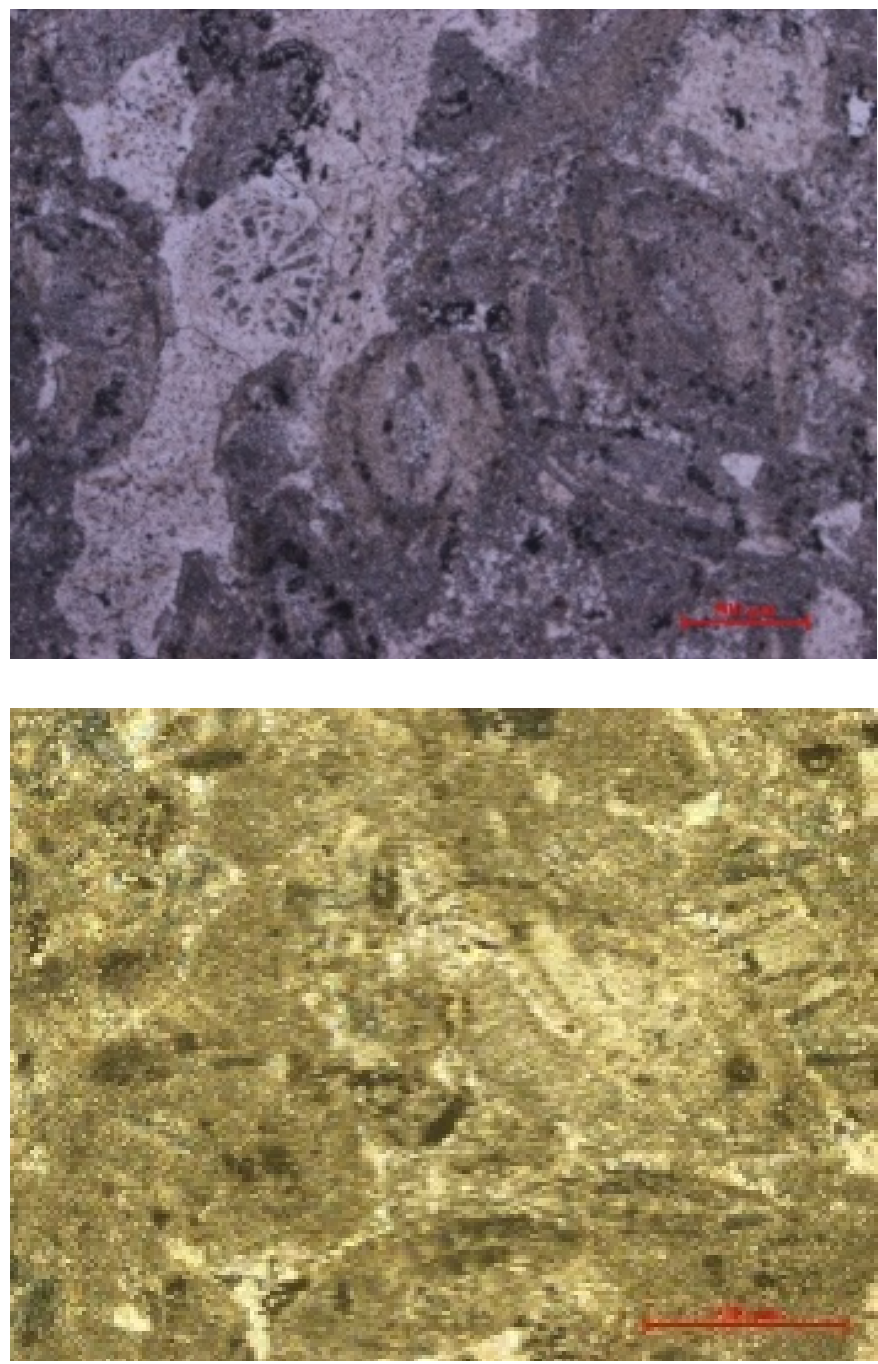

Figure 10. The samples investigated under polarizing microscope Crossed Nicole and the samples investigated under polarizing microscope (PLM).

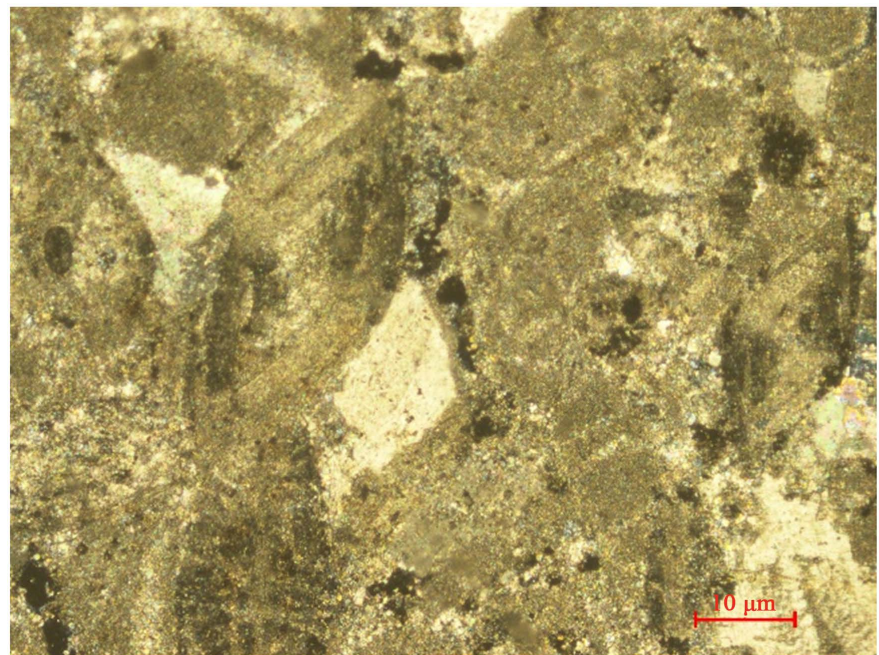

Figure 11. Recrystallization and alteration of primary carbonate (calcite) detected in the microfossils and shell fragments to form a coarser grained calcite. 


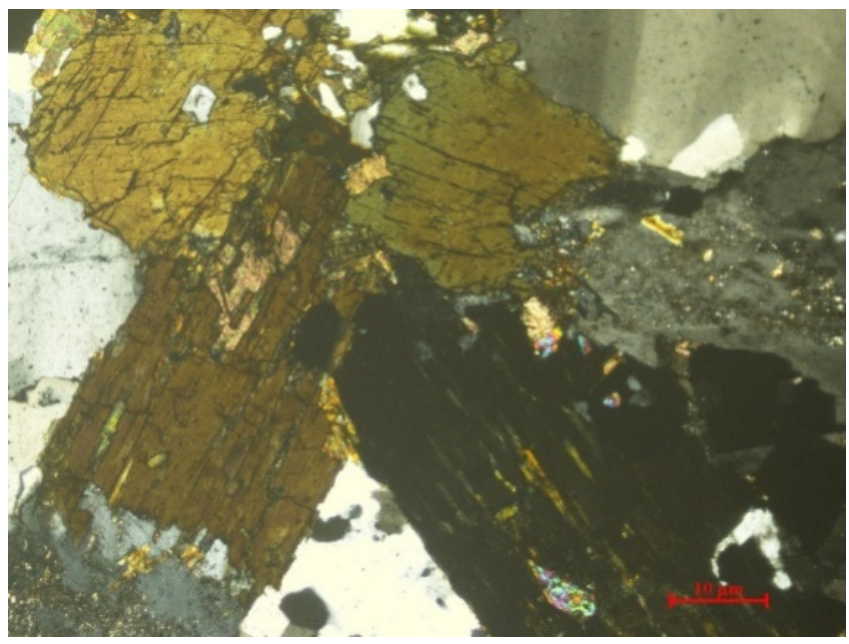

Figure 12. The main composition of granite mainly of alkali feldspar (microcline \& orthoclase perthite), quartz, plagioclase, biotite and hornblende together with accessory of titanite, zircon, apatite and opaque minerals.
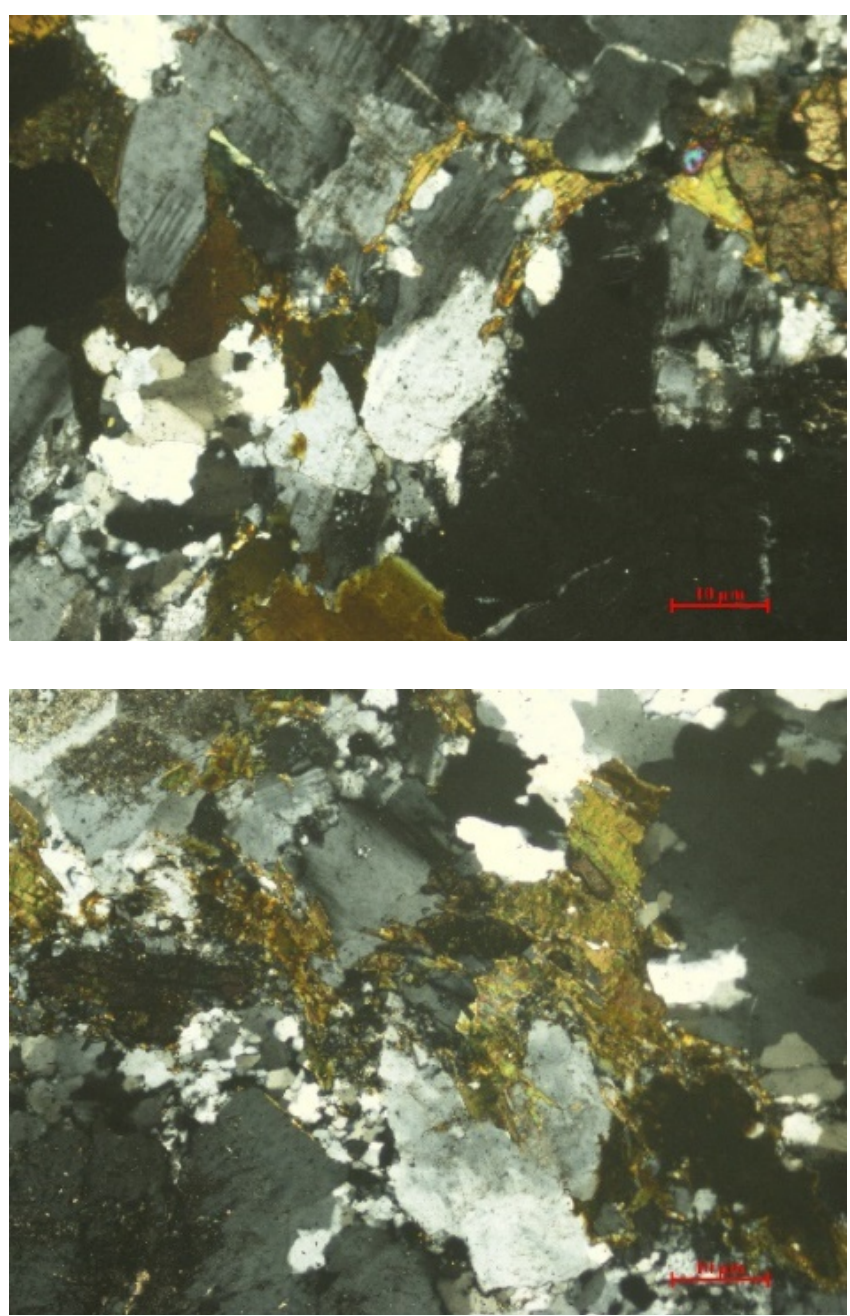

Figure 13. Alkali and plagioclase feldspars are partially altered to sericite, carbonates and clay minerals and Mafic minerals (biotite and hornblende) are partially to highly altered to chlorite with liberation of iron oxides at its cleavage planes and borders. 


\section{- Investigation of limestone and granite with Scanning electron micro- scope (SEM) with EDX.}

Scanning electron microscope used to investigate the surface of archaeological limestone and its state of disintegration and alteration, this investigation is operated with elemental analysis to confirm the results of analysis studies and to identify the elements which caused the alteration for the stone. The specification of the instrument is Using SEM Model Quanta 250 FEG (Field Emission Gun) attached with EDX Unit (Energy Dispersive X-ray Analyses), with accelerating voltage $30 \mathrm{KV}$, magnification $14 \mathrm{x}$ up to $1,000,000$ and resolution for Gun.1n). Limestone investigated under scanning electron microscope with EDX with various spots upon the samples as shown in Figure 14, where the results are; $\mathrm{Ca}$, $\mathrm{K}, \mathrm{Si}, \mathrm{O}$ and $\mathrm{C}$. The texture of stone sample is not homogenous with many pores as a result of chemical and mechanical weathering of stone. Granite also investigated under SEM with EDX to investigate the effect of chemical and mechanical weathering as shown in Figure 15.

\section{- Investigation of mortar with polarizing microscope (PLM/CN).}

The texture is very fine to coarse-grained, showing prophyrtic texture (coarse-grained of quartz and rock fragments enclosed in fine-grained matrix).

\section{C:ISharedData |2018\abdelrahman mohamed\7-5-2018\Sample (3) Photo No 07(e). spc}

Label A: Sample (3) Photo No 07 (e)

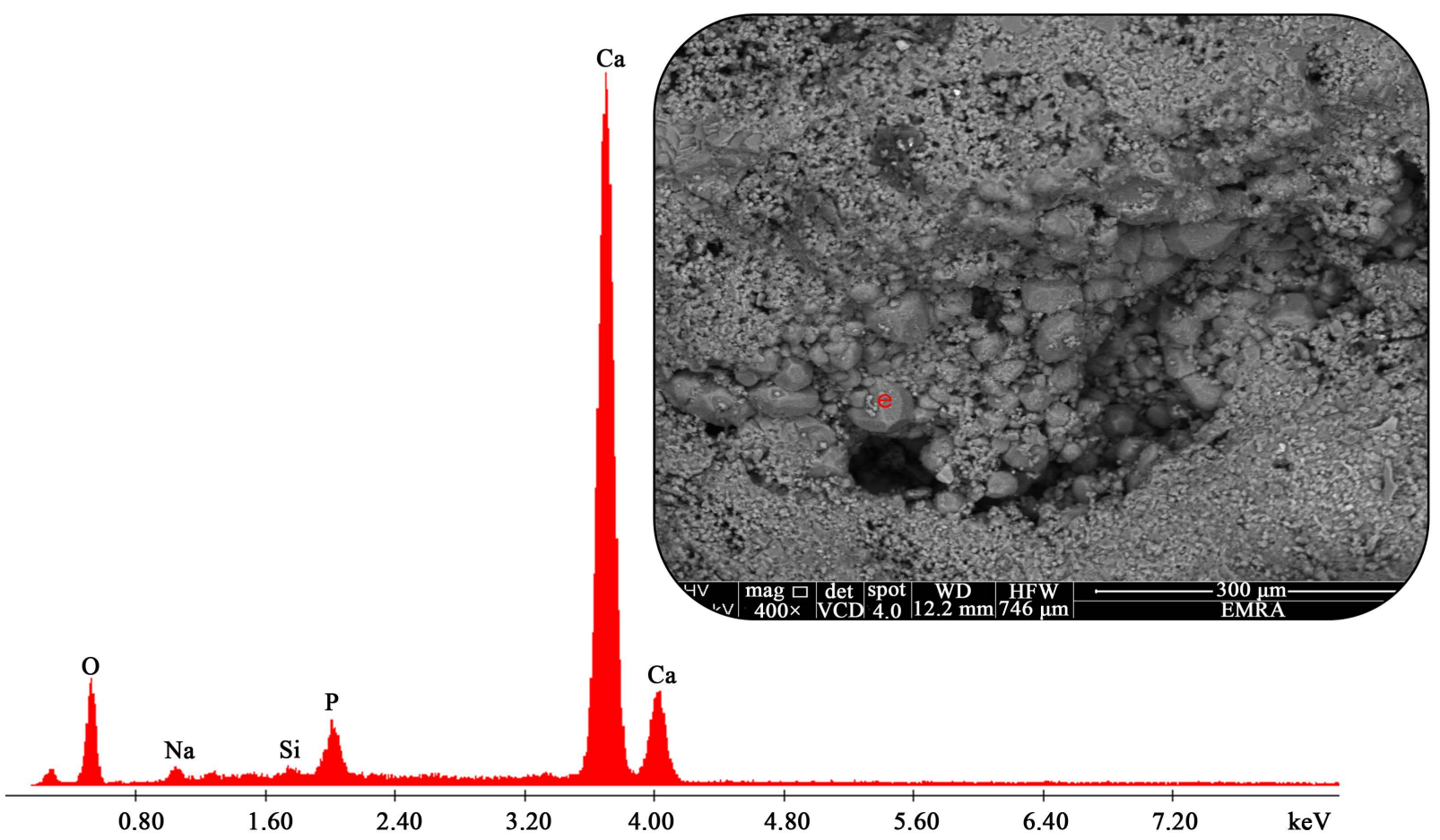

Figure 14. SEM image with EDX for area called e (Calcite crystal), where the results are; $\mathrm{Ca}, \mathrm{Na}, \mathrm{Si}$, and $\mathrm{O}$. the texture of stone sample is not homogenous with many pores as a result of chemical and mechanical weathering of stone which lead to disintegration and alteration. 


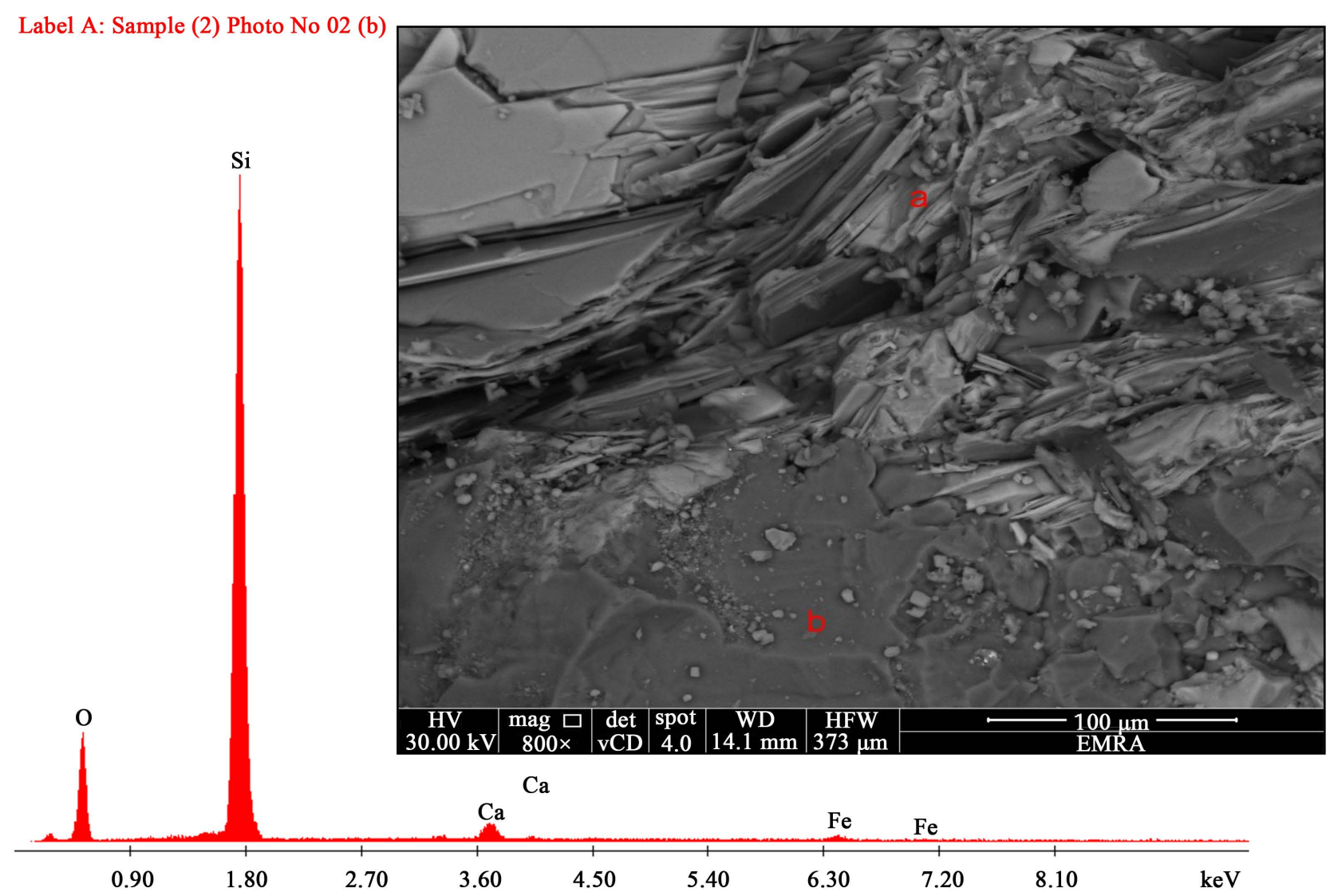

Figure 15. SEM image with EDX, the granite is suffering from high disintegration and alteration, the elemental analysis shows that this part is composed mainly from quartz.

Considerable number of irregular pores and cavities are detected in the sample. Mineral composition of the sample is very fine-grained to coarse and composed of rock fragments, quartz, cemented by very fine-grained matrix of carbonate (mainly calcite) admixed with gypsum and/or basanite and minor amount of iron oxides associated with rare amounts of halite, feldspars and mafic minerals (biotite, muscovite and epidote) and opaque minerals. Rock fragments are represented by mainly carbonate fragments (calcite), chert and flint present and occurs as coarse to medium-grained of rounded to subangular outlines and scattered in very fine-grained of the sample matrix. Few microfossils are observed scattered in the rock fragment of calcite. Quartz and feldspars occur as medium to fine-grained of subrounded to subangular outlines and cemented by a mixture of very fine-grained matrix. Iron oxides and opaque minerals occur as fine to medium-grained scattered in the sample. Halite represents by traces enclosed in some pore spaces. Mafic minerals present as fine-grained, and observed in the matrix of the sample. Significant number of irregular pores in different shapes and sizes are scattered in the sample (Figure 16). Alterations of mortar where the essential components are affected by deformation shown by micro-cracks in quartz, rock fragments and also corroded boundaries and edges. 


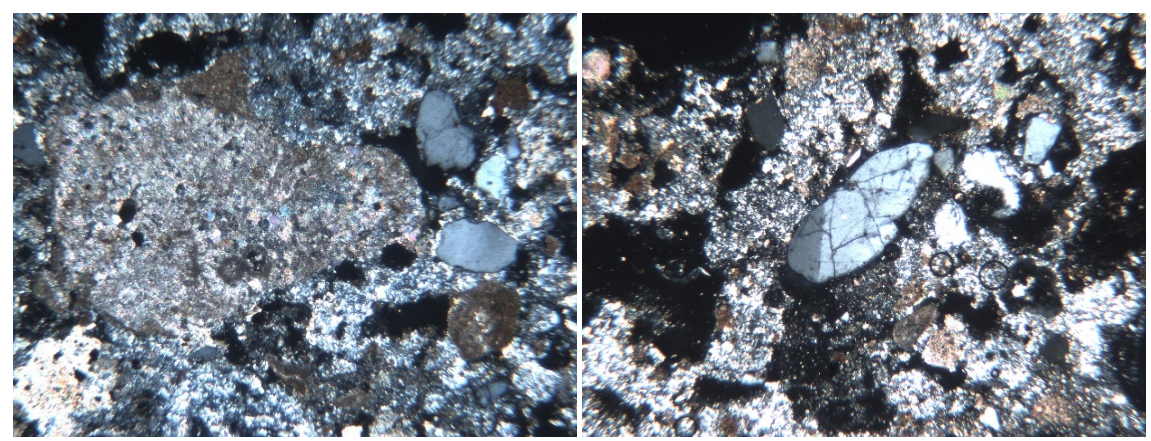

Figure 16. The archaeological building mortar under polarizing microscope and the sample is very fine-grained to coarse and composed of rock fragments, quartz, cemented by very fine-grained matrix of carbonate (mainly calcite) admixed with gypsum and/or basanite and minor amount of iron oxides associated with rare amounts of halite, feldspars and mafic minerals (biotite, muscovite and epidote) and opaque minerals.

Several pore spaces and cavities (vugs) are present due to alteration and dissolution over the essential components in the sample such as calcite and evaporites (bassanite \& gypsum). Biotite and mafic minerals are partly to be highly affected by alteration.

\section{- Investigation of mortar with Scanning electron microscope (SEM) with} EDX.

The archaeological mortar has been investigated under SEM to investigate its morphology and make elemental analysis as shown in Figure 17.

\subsection{Engineering Properties of Construction Materials}

Generally, the measurements of physical properties seem to be the most important to shows the behaviour of stone and its characteristics after weathering and degradation as a result of chemical or mechanical weathering so the physical properties are changing from time to time according to the severity of weathering factors [24]. In the archaeological site of El-Ashmonein there are different kind of building materials the most dominant are Granite and Limestone which used in as a building material for columns in the site. So, there are two kinds of stone with different origin and locality and different geotechnical properties.

\subsubsection{Physical Characteristics of Limestone and Granite}

Several geotechnical properties had been measured and tested such as specific gravity, apparent density, porosity, water absorption and seismic analyser test to identify the Compressional waves and shear wave velocity of granite and limestone. Ten cubic samples have been weighted naturally, after drying in $105^{\circ}$. In the oven the samples inside the oven for drying, and also the author measured the saturated weight of samples as shown in Table 9 displays the weight average values of granite cubic samples, naturally, after drying every cycle 10 hours, and saturated every cycle 24 hours for limestone and Table 10 for granite and Table 11 shows different geo-physical properties of granite and Table 12 for granite. 

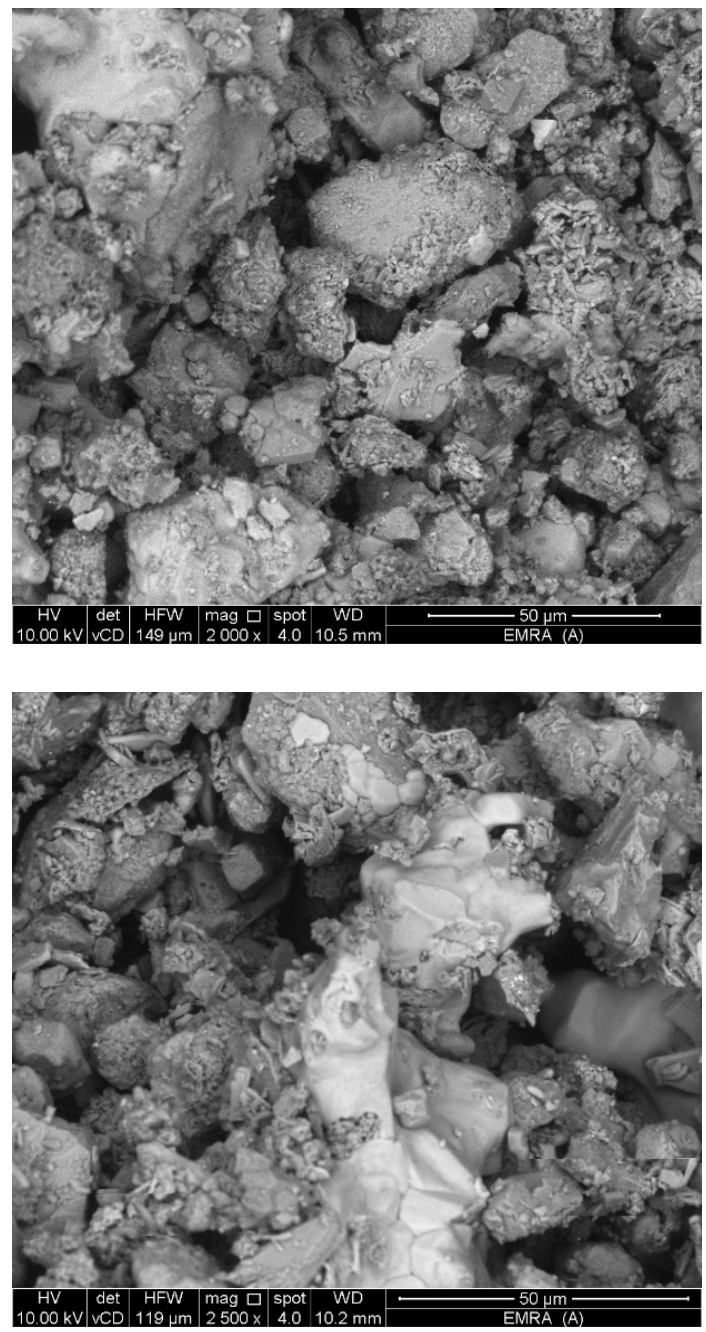

Label A: A

C: SharedData $\mid 2018 \backslash$ abdelrahman mohamed $\backslash 1-8-2018 \backslash A-1 . s p c$

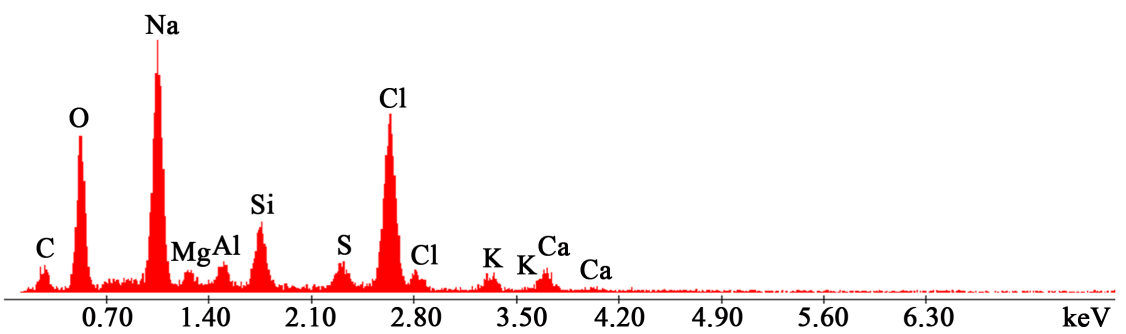

Figure 17. SEM image with EDX, where we can find high disintegration and alteration as a resul of mechanical and chemical weathering.the elemets are $\mathrm{Na}, \mathrm{Si}, \mathrm{Ca}, \mathrm{Mg}, \mathrm{Cl}, \mathrm{K}, \mathrm{Al}$ and $\mathrm{C}$. These elemnts indicates that there is an impact for salt weathering on mortar components. 
Table 9. The weight average values of granite cubic samples, naturally, after drying every cycle 10 hours, and saturated every cycle 24 hours.

\begin{tabular}{cccccccccccc}
\hline Sample No. & 1 & 2 & 3 & 4 & 5 & 6 & 7 & 8 & 9 & 10 & Average \\
\hline Natural weight $(\mathrm{gm})$ & 337.6 & 360.7 & 361.3 & 348 & 331.8 & 355.9 & 324 & 337.8 & 356.7 & 323.7 & 343.75 \\
Dried weight (gm) & 337 & 360 & 360.4 & 346.6 & 331.2 & 354.3 & 323.6 & 337.3 & 355.3 & 322.1 & 342.78 \\
Saturated weight (gm) & 339 & 361 & 361.8 & 348.6 & 332.6 & 356.7 & 324.5 & 338.5 & 357 & 322.9 & 343.36 \\
Water content (W) (\%) & 0.6 & 0.2 & 0.3 & 0.6 & 0.5 & 0.7 & 0.2 & 0.3 & 0.5 & 0.2 & 0.1 \\
\hline
\end{tabular}

Table 10. Different physical properties of collected granite samples.

\begin{tabular}{|c|c|c|c|c|c|c|c|c|c|c|}
\hline Sample No. & 1 & 2 & 3 & 4 & 5 & 6 & 7 & 8 & 9 & 10 \\
\hline $\mathrm{L}$ (length) $\mathrm{cm}$ & 5.1 & 5.3 & 5.00 & 5.10 & 5.2 & 5.3 & 5.3 & 500 & 5.7 & 5.00 \\
\hline $\mathrm{W}$ (width) $\mathrm{cm}$ & 5.4 & 5.00 & 5.1 & 5.2 & 5.4 & 5.13 & 5.2 & 5.2 & 5.1 & 5.4 \\
\hline $\mathrm{H}$ (height) $\mathrm{cm}$ & 5.00 & 5.2 & 5.6 & 5.1 & 5.00 & 5.00 & 5.1 & 5.4 & 5.6 & 5.11 \\
\hline $\mathrm{V}$ (Volume) $\mathrm{cm}^{3}$ & 137.7 & 137.9 & 142.9 & 135.2 & 140.5 & 136 & 140.6 & 140.4 & 162.8 & 138 \\
\hline $\mathrm{M}$ (mass) gm & 337.6 & 360.7 & 361.3 & 348 & 331.8 & 355.9 & 324 & 337.8 & 356.7 & 323.7 \\
\hline Weight $(\mathrm{kN})=\mathrm{Mg}$ & 3308.48 & 3534.86 & 3540.74 & 3410.4 & 3251.64 & 3487.82 & 3175.2 & 3310.44 & 3495.66 & 3172.26 \\
\hline Density $(\rho) \mathrm{M} / \mathrm{V}\left(\mathrm{g} / \mathrm{m}^{3}\right)$ & 1.7 & 2.3 & 2.7 & 2.6 & 2.2 & 2.6 & 2.1 & 2.2 & 2.5 & 2.3 \\
\hline UW (unit weight) $(\gamma)\left(\mathrm{g} / \mathrm{cm}^{3}\right)(\rho \mathrm{g})$ & 16.7 & 22.6 & 26.5 & 25.5 & 21.6 & 25.5 & 20.6 & 21.6 & 24.6 & 22.6 \\
\hline Specific gravity $(\mathrm{GS})=\rho / \rho_{\mathrm{w}}$ & 1.7 & 2.3 & 2.7 & 2.6 & 2.2 & 2.6 & 2.1 & 2.2 & 2.5 & 2.3 \\
\hline $\begin{array}{c}\left.\text { (Absolute } \phi_{\mathrm{a}}\right) \text { Total } \\
\text { Porosity }(\%) \phi \mathrm{v}_{\mathrm{v}}\left(\mathrm{w}_{1}-\mathrm{w}_{2}\right) / \mathrm{v}_{\mathrm{t}}\end{array}$ & 0.01 & 7.2 & 9.8 & 0.01 & 10 & 0.01 & 6.5 & 8.6 & 0.01 & 5.8 \\
\hline
\end{tabular}

Table 11. The weight average values of limestone cubic samples, naturally, after drying every cycle 10 hours, and saturated every cycle 24 hours.

\begin{tabular}{|c|c|c|c|c|c|c|c|c|c|c|}
\hline Sample No. & 1 & 2 & 3 & 4 & 5 & 6 & 7 & 8 & 9 & 10 \\
\hline Natural weight (gm) & 271 & 261.8 & 261.3 & 261.2 & 263 & 269.6 & 268.5 & 271.5 & 260.8 & 266.1 \\
\hline Dried weight (gm) & 258.7 & 253.2 & 253.2 & 256.9 & 257.5 & 261.6 & 262.5 & 264.8 & 253.7 & 257.7 \\
\hline Saturated weight (gm) & 264.8 & 274.6 & 273.3 & 277.6 & 277.6 & 282.9 & 284.7 & 285.2 & 275 & 278.5 \\
\hline Water content (W) (\%) & 2.3 & 7.7 & 7.3 & 7.5 & 7.2 & 7.3 & 7.8 & 7.1 & 7.8 & 7.5 \\
\hline
\end{tabular}

Table 12. The results of physical properties for the limestone samples.

\begin{tabular}{|c|c|c|c|c|c|c|c|c|c|c|}
\hline Sample No. & 1 & 2 & 3 & 4 & 5 & 6 & 7 & 8 & 9 & 10 \\
\hline $\mathrm{L}$ (length) $\mathrm{cm}$ & 5.9 & 5.7 & 5.15 & 5.20 & 5.1 & 5.3 & 5.6 & 5.4 & 5.17 & 5.1 \\
\hline $\mathrm{W}$ (width) $\mathrm{cm}$ & 5.9 & 5.00 & 5.1 & 5.12 & 5.14 & 5.13 & 5.20 & 5.2 & 5.5 & 5.14 \\
\hline $\mathrm{H}$ (Hight) $\mathrm{cm}$ & 5.7 & 5.22 & 5.00 & 5.1 & 5.44 & 5.00 & 5.13 & 5.23 & 5.12 & 5.19 \\
\hline V (Volume) & 198.5 & 148.2 & 131.3 & 135.8 & 142.7 & 136 & 149.2 & 146.9 & 145.6 & 136 \\
\hline M (Mass) gm & 271 & 261.8 & 261.3 & 261.2 & 263 & 269.6 & 268.5 & 271.5 & 260.8 & 266.1 \\
\hline Weight $(\mathrm{KN})=\mathrm{Mg}$ & 2655.9 & 2565.64 & 2560.8 & 2559.8 & 2577.5 & $342,642.08$ & 2631.3 & 2660.7 & 2555.84 & 2607.78 \\
\hline Density $(\rho) \mathrm{M} / \mathrm{V}\left(\mathrm{g} / \mathrm{m}^{3}\right)$ & 1.3 & 1.8 & 2 & 1.6 & 1.9 & 2 & 1.8 & 1.9 & 1.8 & 2 \\
\hline UW (Unite weight) $\left(\mathrm{g} / \mathrm{cm}^{3}\right)(\gamma)(\rho \mathrm{g})$ & 12.8 & 17.7 & 19.7 & 15.7 & 18.7 & 19.7 & 17.7 & 18.7 & 17.3 & 19.7 \\
\hline Specific gravity $(\mathrm{GS})=\rho / \rho_{\mathrm{w}}$ & 1.3 & 1.8 & 2 & 1.6 & 1.9 & 2 & 1.8 & 1.9 & 1.8 & 2 \\
\hline $\begin{array}{c}\left(\text { Absolute } \phi_{\mathrm{a}}\right) \text { Total } \\
\text { Porosity }(\%) \phi \mathrm{v}_{\mathrm{v}}\left(\mathrm{w}_{1}-\mathrm{w}_{2}\right) / \mathrm{v}_{\mathrm{t}}\end{array}$ & 0.03 & 014 & 0.15 & 0.15 & 0.14 & 0.15 & 0.14 & 0.04 & 0.14 & 0.15 \\
\hline
\end{tabular}




\subsubsection{In-Situ and Laboratory Mechanical Testing}

\section{First: The nondestructive testing:}

\section{1) Seismic analyzer test ( $P$ - and S-waves (body waves) body (seismic) waves}

Seismic techniques, which are known as nondestructive geophysical methods, are commonly used by engineers working in various fields such as mining, civil, and geotechnical engineering. They are frequently employed to investigate certain properties of rocks [25]. Tektronix TAS250 Digital Oscilloscope (seismic analyzer) at faculty of science, geophysical department, Cairo University had been used as a nondestructive technique to identify different geo physical and mechanical properties of limestone and granite, as shown in Figure 18. So, the samples tested to identify the compressional waves and shear wave velocity (seismic waves/body waves) of both granite and limestone as a construction material for the archaeological columns. The samples are cylinders diameter $5 \mathrm{~cm}$ and Height $10 \mathrm{~cm}$. The results of the seismic test for two samples from granite and two samples from limestone are shown in Table 13 granite, and Table 14 limestone.

\section{2) Schmidt hammer test}

Equotip had been used as a nondestructive method for assessment the mechanical characteristics, it is carried out on 48 free standing granite columns and their bases and crowns. Figure 19 shows the plan of basilica church and distribution of columns and their numbers for Schmidt hammer test. This study aims to
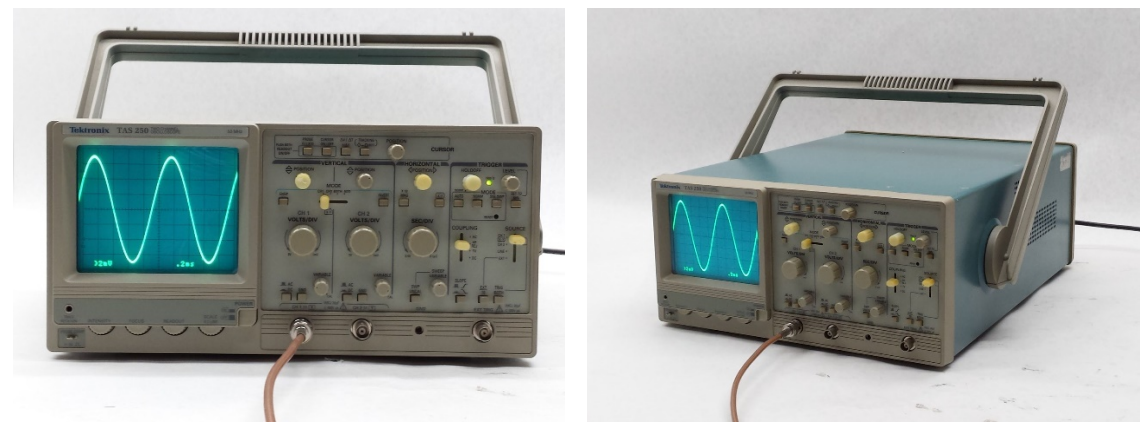

Figure 18. Tektronix TAS250 Digital Oscilloscope (seismic analyzer). The instrument which used for identification of seismic waves for the stone samples, this test carried out at faculty of science, geophysics department, Cairo University.

Table 13. Compressional waves and shear wave velocity of granite cylindrical samples.

\begin{tabular}{ccc}
\hline No. of Sample & Compressional Waves $(\mathrm{p})$ & Shear Waves Velocity $(\mathrm{s})$ \\
\hline Sample 47 & 1900 & 1470 \\
Sample 48 & 2688 & 1900 \\
\hline
\end{tabular}

Table 14. Compressional waves and shear wave velocity of limestone cylindrical samples.

\begin{tabular}{ccc}
\hline No. of Sample & Compressional Waves $(\mathrm{p})$ & Shear Waves Velocity $(\mathrm{s})$ \\
\hline Sample 5 & 2090 & 1960 \\
Sample 9 & 2667 & 2380 \\
\hline
\end{tabular}




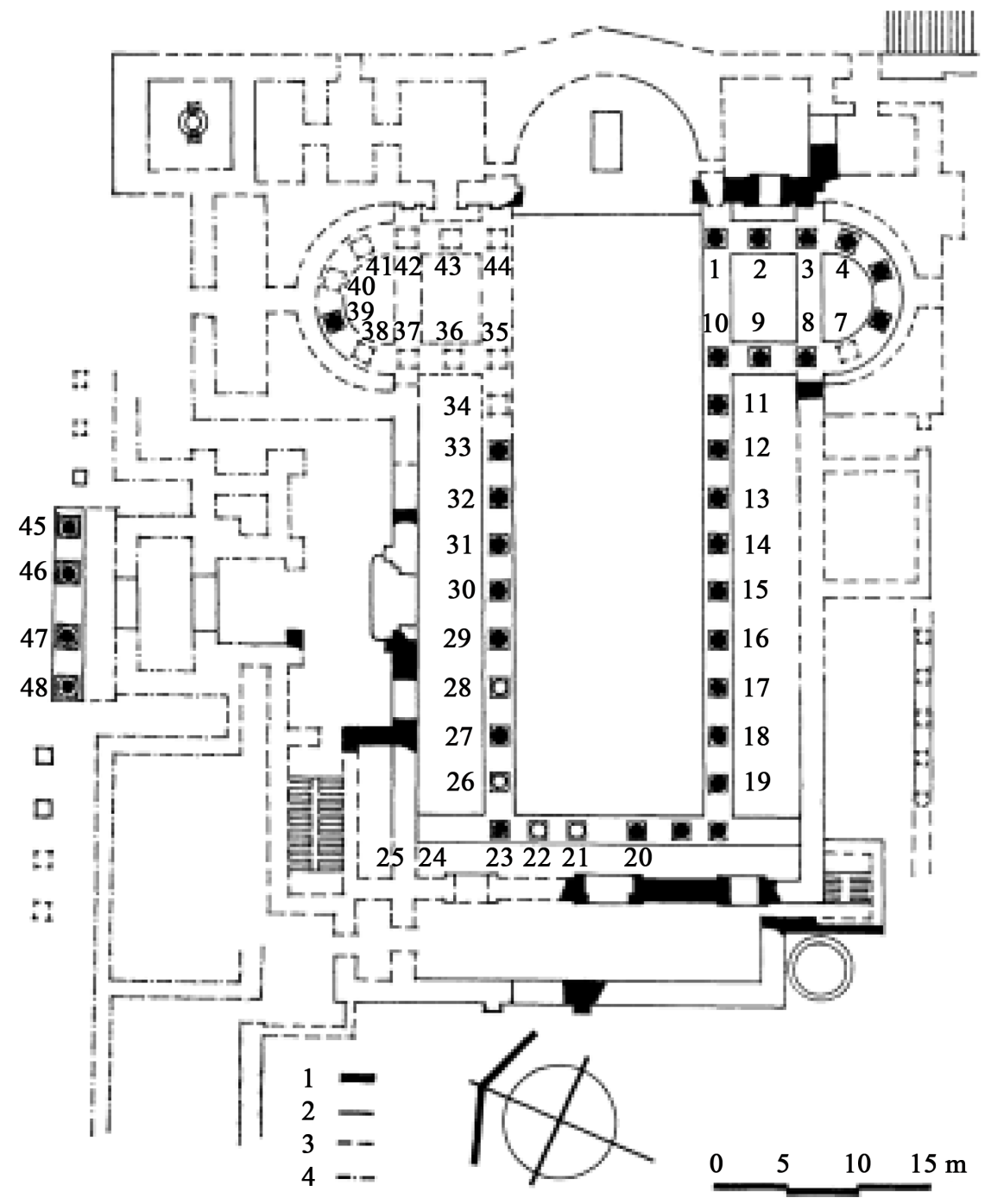

Figure 19. The plan of basilica church and distribution of columns and their numbers for Schmidt hammer test.

estimate the strength of stone as seen in Figure 20 and to increase the accuracy of Calculating the strength, using the nondestructive test (NDT) surface hardness rebound value, material design parameters and regression analysis. Figure 21: Plotting the Schmidt hammer rebound number (RN) versus the Uniaxial Compressive Strength of limestone. Figure 22: Plotting the Schmidt hammer rebound number (RN) versus the Uniaxial Compressive Strength of granite.

\section{Second: The destructive testing}

\section{1) Compressive strength test}

Three limestone and three granite samples of construction material of columns were prepared to carry out the uniaxial unconfined compressive strength of intact core samples diameter $5 \mathrm{~cm}$ and height $10 \mathrm{~cm}$ as seen in Table 15 and Table 16. Figure 23 shows preparation of the samples for mechanical testing and ultrasonic testing. The mechanical testing results for limestone and granite are shown in Figure 24 and Figure 25. 

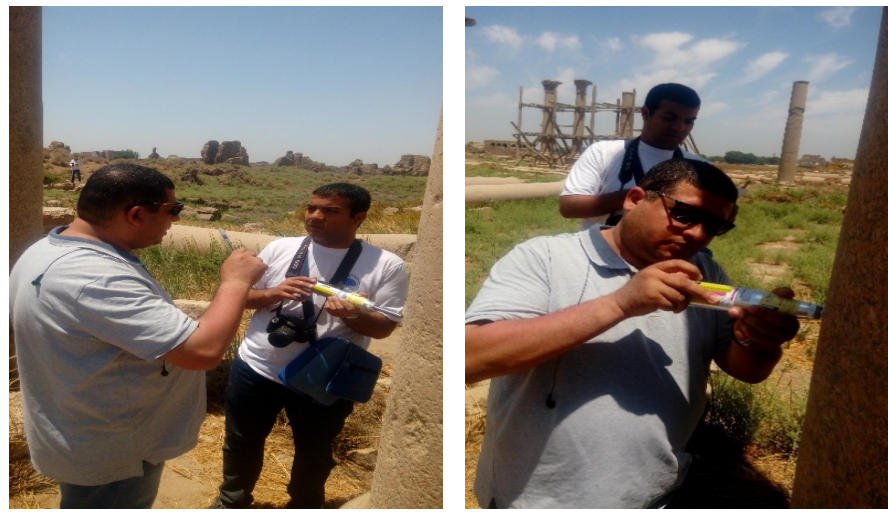

Figure 20. The researchers during using Equotip for granite columns in the site.
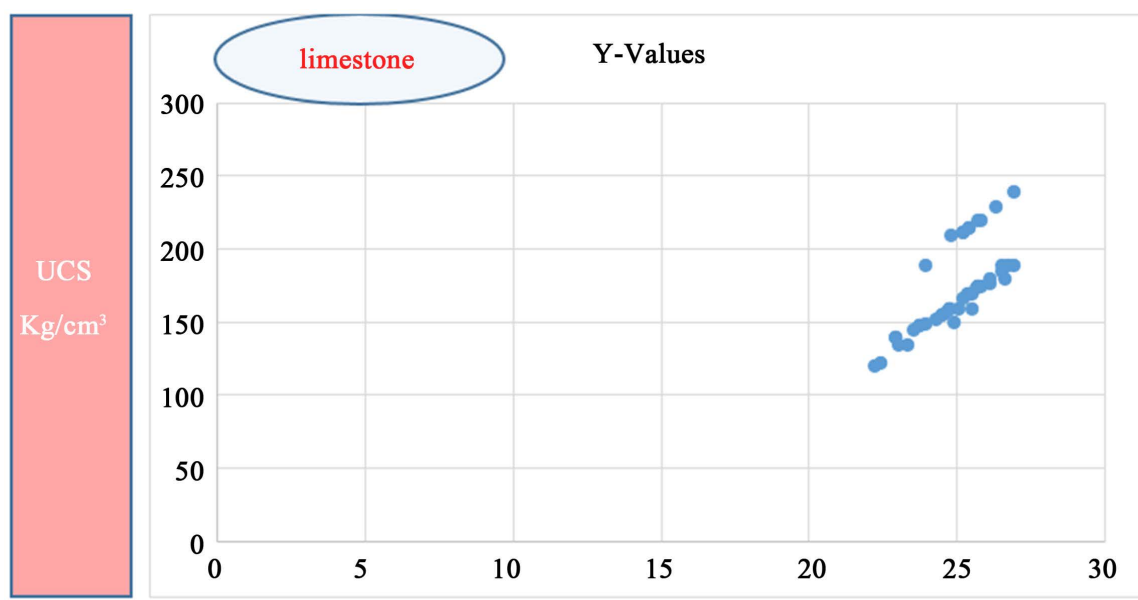

$\mathrm{R}=$ Hammer Rebounds

Figure 21. Plotting the Schmidt hammer rebound number (RN) versus the Uniaxial Compressive Strength of limestone.
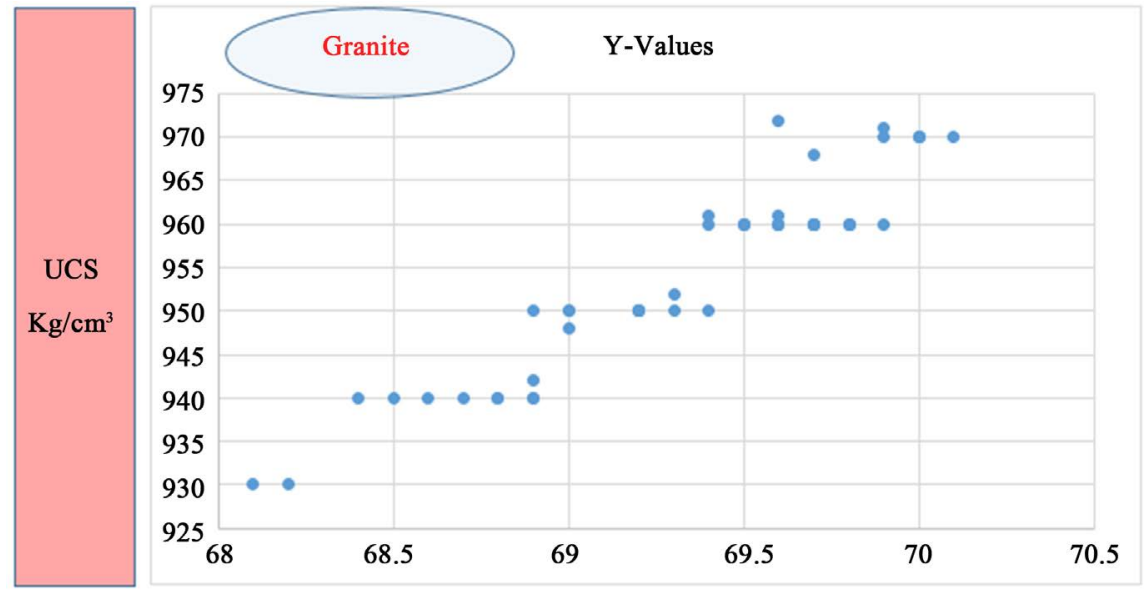

$\mathbf{R}=$ Hammer Rebounds

Figure 22. Plotting the Schmidt hammer rebound number (RN) versus the Uniaxial Compressive Strength of granite. 

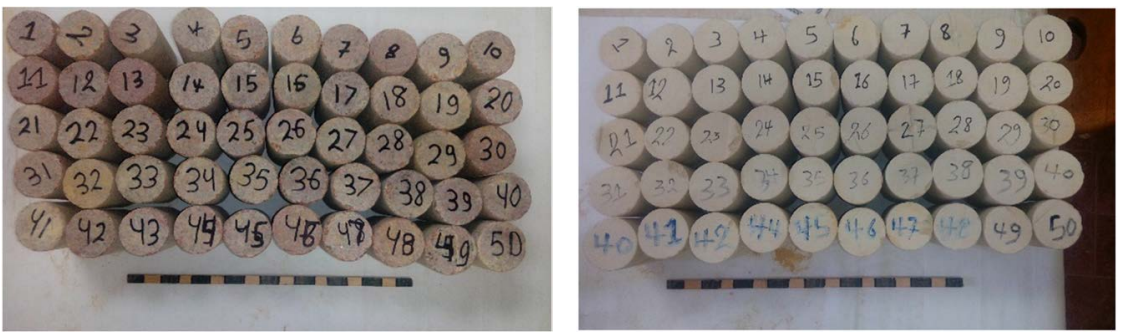

Figure 23. Preparation of the samples for mechanical testing and ultrasonic testing.

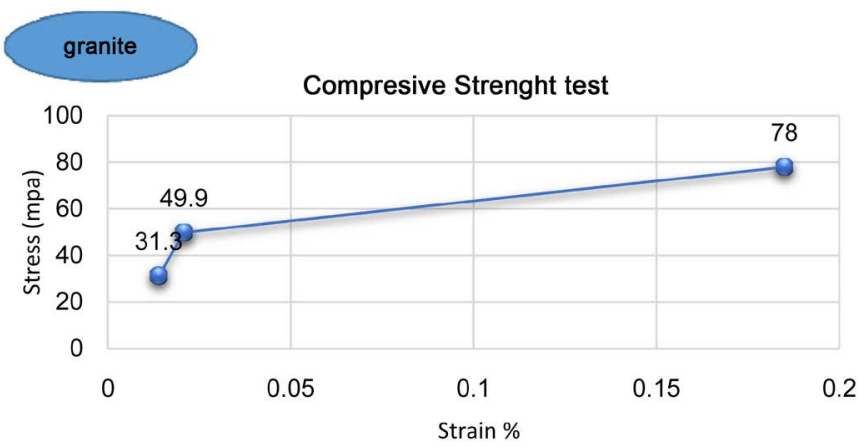

Figure 24. The relationship between stress/strain for granite.

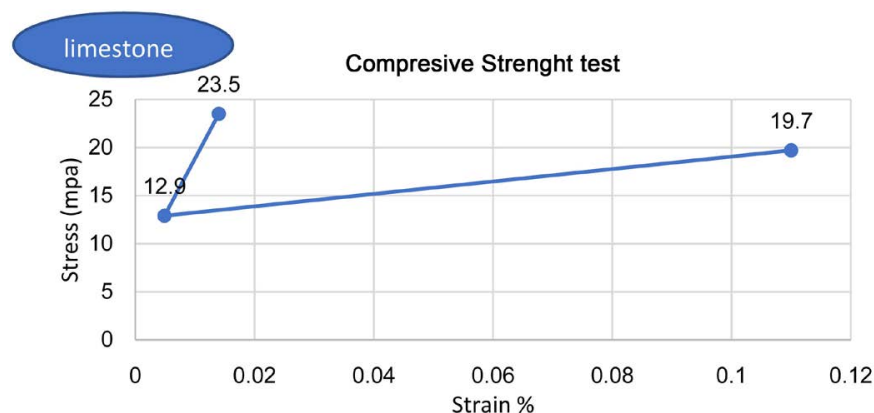

Figure 25. The relationship between stress/strain for limestone.

Table 15. Mechanical testing results for granite.

\begin{tabular}{ccccccc}
\hline $\begin{array}{c}\text { Samples } \\
(\text { No. })\end{array}$ & $\begin{array}{c}\mathrm{P}(\text { Pressure }) \\
(\mathrm{kN})\end{array}$ & $\begin{array}{c}\Delta \mathrm{L} \\
(\mathrm{mm})\end{array}$ & $\begin{array}{c}\text { Area } \\
(\mathrm{mm})^{2}\end{array}$ & Strain \% & $\begin{array}{c}\text { Stress } \\
(\mathrm{MPa})\end{array}$ & $\begin{array}{c}\mathrm{M} \text { (Youngs Modulas) } \\
(\mathrm{GPa} \text { or kN/mm² }\end{array}$ \\
\hline $11 \mathrm{G}$ & 161 & 1.9 & 2054.616 & 0.0185 & 78 & 4.22 \\
$17 \mathrm{G}$ & 96 & 2.1 & 1923.446 & 0.0208 & 49.9 & 2.39 \\
$18 \mathrm{G}$ & 59 & 1.4 & 1884.785 & 0.0139 & 31.3 & 2.25 \\
\hline
\end{tabular}

Table 16. The mechanical test results for limestone.

\begin{tabular}{ccccccc}
\hline $\begin{array}{c}\text { Samples } \\
(\text { No. })\end{array}$ & $\begin{array}{c}\mathrm{P}(\text { Pressure }) \\
(\mathrm{kN})\end{array}$ & $\begin{array}{c}\Delta \mathrm{L} \\
(\mathrm{mm})\end{array}$ & $\begin{array}{c}\text { Area } \\
\left(\mathrm{mm}^{2}\right)\end{array}$ & Strain \% & $\begin{array}{c}\text { Stress } \\
(\mathrm{MPa})\end{array}$ & $\begin{array}{c}\mathrm{M} \text { (Youngs Modulas) } \\
(\mathrm{GPa} \text { or kN/mm² }\end{array}$ \\
\hline $13 \mathrm{~L}$ & 38 & 1.1 & 1923.446 & 0.011 & 19.7 & 1.79 \\
$5 \mathrm{~L}$ & 23.5 & 0.5 & 1808.64 & 0.0049 & 12.9 & 2.63 \\
$1 \mathrm{~L}$ & 43 & 1.4 & 1823.743 & 0.014 & 23.5 & 1.67 \\
\hline
\end{tabular}




\section{2) Flexural strength test}

Flexural strength is a measure of the tensile strength, it is useful in knowing the quality of natural stone by identifying the stress, strain and modulus of elasticity of naturals stone used in columns as seen in Table 17 and Table 18, also Figure 26 and Figure 27 for each limestone and granite used in columns [26] [27] [28] [29] [30].

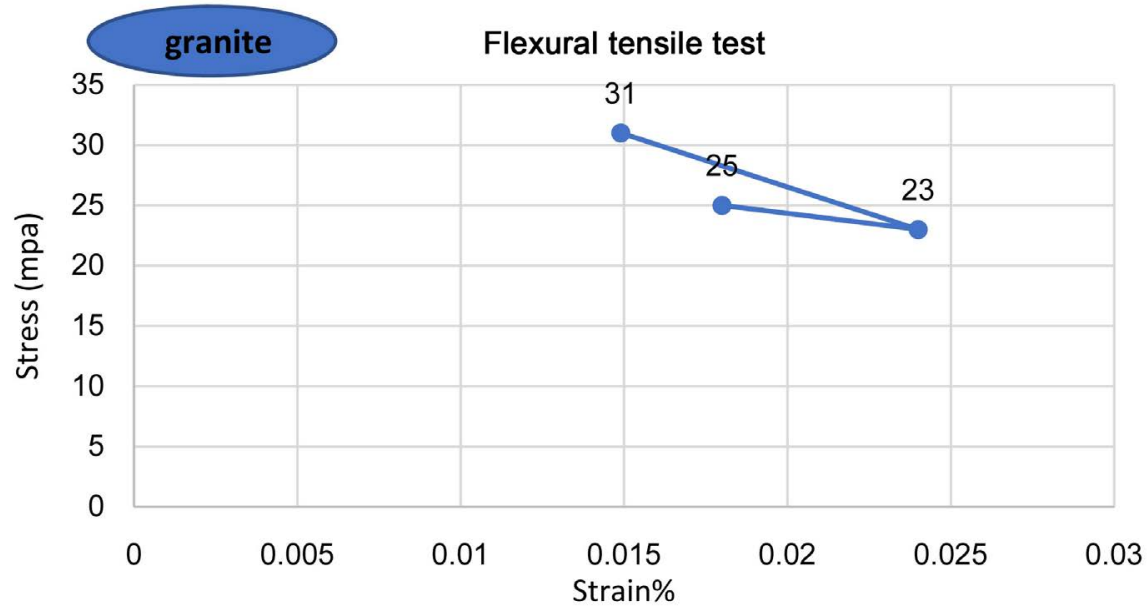

Figure 26. The relationship between stress/strain by Flexural tensile test for granite.

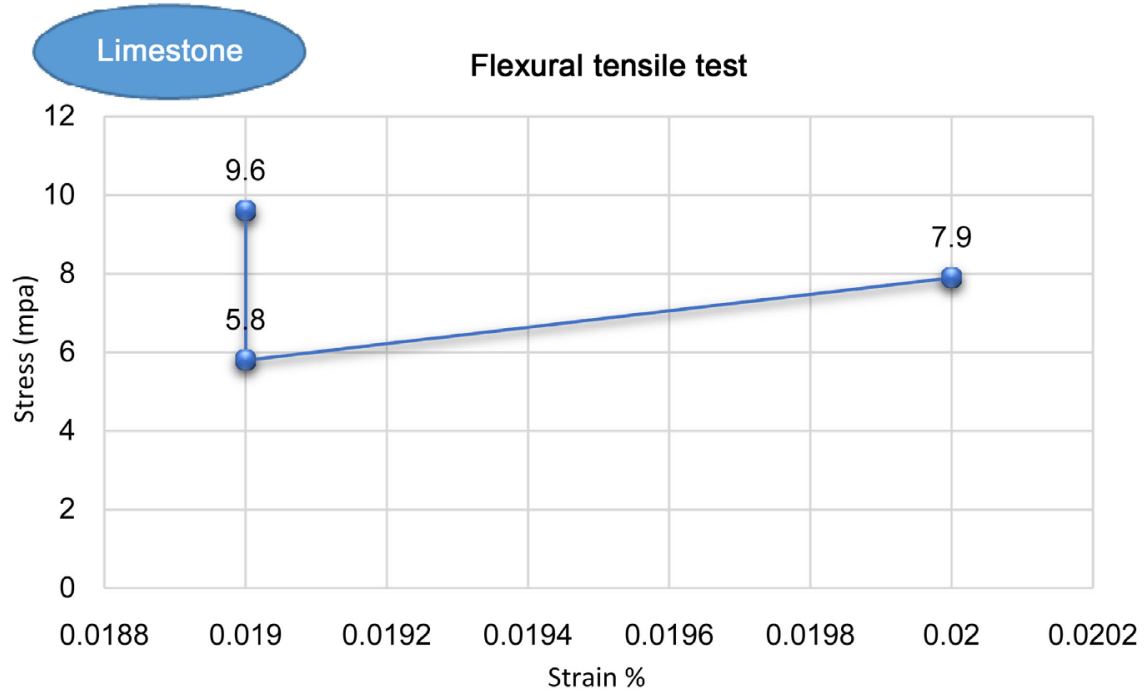

Figure 27. The relationship between stress/strain by Flexural tensile test for limestone.

Table 17. The test results of flexural strength for granite.

\begin{tabular}{cccccc}
\hline $\begin{array}{c}\text { Samples } \\
(\text { No. })\end{array}$ & $\begin{array}{c}\text { P (Pressure }) \\
(\mathrm{KN})\end{array}$ & $\begin{array}{c}\Delta \mathrm{L} \\
(\mathrm{mm})\end{array}$ & Strain (\%) & $\begin{array}{c}\text { Stress } \\
(\mathrm{MPa})\end{array}$ & $\begin{array}{c}\text { E (Youngs Modulas) } \\
(\mathrm{GPa} \text { or kN/mm })\end{array}$ \\
\hline $19 \mathrm{G}$ & 16 & 1.8 & 0.018 & 25 & 1.38 \\
$20 \mathrm{G}$ & 14.5 & 2.5 & 0.024 & 23 & 0.958 \\
$43 \mathrm{G}$ & 17.5 & 1.5 & 0.0149 & 31 & 2.08 \\
\hline
\end{tabular}


Table 18. The test results of Flexural strength for granite.

\begin{tabular}{cccccc}
\hline $\begin{array}{c}\text { Samples } \\
(\text { No. })\end{array}$ & $\begin{array}{c}\mathrm{P}(\text { Pressure }) \\
(\mathrm{KN})\end{array}$ & $\begin{array}{c}\Delta \mathrm{L} \\
(\mathrm{mm})\end{array}$ & $\begin{array}{c}\text { Strain } \\
\%\end{array}$ & $\begin{array}{c}\text { Stress } \\
(\mathrm{MPa})\end{array}$ & $\begin{array}{c}\mathrm{E} \text { (Youngs Modulas) } \\
(\mathrm{GPa} \text { or kN/mm })\end{array}$ \\
\hline $3 \mathrm{~L}$ & 4.5 & 2 & 0.02 & 7.9 & 0.395 \\
$4 \mathrm{~L}$ & 3.5 & 1.9 & 0.019 & 5.8 & 0.305 \\
$11 \mathrm{~L}$ & 6 & 2 & 0.019 & 9.6 & 0.505 \\
\hline
\end{tabular}

\section{Conclusions}

The present study includes the main phase of integrated proposal for the conservation of the early basilica church from the geo-environmental and structural engineering views. After introducing the geological seism tectonic settings, a hazard map of Al-Ashmonein area is presented. It also includes the structural deficiencies and their detailed study, engineering parameters, probability of failure, and microzoning of the critical parts of the free standing columns.

This current study is so important for giving intensive information about construction materials used especially in basilica church. After description of the basilica church structurally and architecturally, the destruction for the whole archaeological site causes is explained. Also, this study includes the geochemical, geomechanical and geophysical characteristics.

Petrographically, recrystallization of primary carbonate (calcite) is detected in the microfossils and shell fragments to form a coarser grained calcite. Some pore spaces are detected in the sample due to dissolution of the original constituents such as fossils shell and the granite is affected by alteration and deformation over original constituents. Alkali and plagioclase feldspars are partially altered to sericite, carbonates and clay minerals.

The mechanical properties of the samples are medium poor and are all closely correlated. The construction materials under investigations have an important intrinsic sensitivity to weathering factors especially the static, dynamic actions, ground water and salt weathering effects.

\section{Authors' Contributions}

The whole database construction and analysis are presented in the manuscript had been achieved by the authors. All authors read and approved the submitted manuscript.

\section{Funding}

The authors confirm that he is not currently in receipt of any research funding relating to the research presented in this manuscript.

\section{Conflicts of Interest}

The authors declare that he has no competing interests. 


\section{References}

[1] Hermopolisgréco-romaine-Anthropologie de l'art, 2. http://anthropologiedelart.org/ramage/wp-content/uploads/2013/03/L.-Medini-Her mopolis.pdf

[2] Spencer, A.J. (1982) The Possible Existence of Third Intermediate Period Elite Tombs at El-Ashmunein. British Museum press, London.

[3] Spencer, J. (1983) Excavations at El-Ashmunein I, the Topography of the Site, British Museum Expedition to Middle Egypt. British Museum Publications, London.

[4] Barański, M. (1987-1990) Excavations at the Basilica Site at El-Ashmunein/Hermopolis Magna in 1987-1990. The Polish-Egyptian Archaeological and Preservation Mission.

[5] Badway, M.M. (1996) Study of Treatment and Conservation of the Coptic Ornaments and Paintings on the Columns in the Churches and Other Historical Buildings. Master's Thesis, Faculty of Archeology, Cairo University, Cairo.

[6] Snape, S.R. (1989) A Temple of Domitian at El-Ashmounein, British Museum Expedition to Middle Egypt. British Museum Publications, London.

[7] Shaw, I. and Jameson, R. (Eds.) (1999) A-Z Entries. Blackwell Publishing Ltd., Oxford. https://doi.org/10.1002/9780470753446.ch1

[8] Maehler, H. (2012) Hermopolis Magna (Greco-Roman). The Encyclopedia of Ancient History.

[9] Lippert, S.L. (2012) Codex Hermopolis. The Encyclopedia of Ancient History. https://doi.org/10.1002/9781444338386.wbeah13042

[10] Elsharqwi, B.S. (2005) Minya Governorate Archaeological Sites and Religious Shrines. 2nd Edition, Press of the Supreme Council of Antiquities, Cairo.

[11] Eldin, A.N. (2007) Ancient Monuments Sites and Museums. Faculty of Archaeology, Cairo University, Cairo.

[12] Qadous, E. (2010) Monuments of Egypt in Greco Roman Era. Elhadry Press, Alexandria.

[13] Bommas, M. and Harrisson, J. (2014) Memory and Urban Religion in the Ancient World. Bloomsbury Publishing, London.

[14] Wace, A.J.B., Megaw, A.H.S., et al. (1959) Hermopolis Magna/Ashmunein. The Ptolemaic Sanctuary and the Basilica, Alexandria.

[15] Atiya, A.S. (1991) Ashmunein. The Coptic Encyclopedia, New York.

[16] Capuani, M, et al. (2002) Christian Egypt. The American University in Cairo Press, Cairo.

[17] Spencer, J. (1989) Excavations at El-Ashmunein II, the Temple Area, British Museum Expedition to Middle Egypt. British Museum Publications, London.

[18] Dunn, J. (2018) Typology of Ancient Egyptian Christian Churches. http://www.touregypt.net/featurestories/churchtypology.htm

[19] Butler, A.J. (1884) Ancient Coptic Churches of Egypt. Oxford at the Clarendon Press, London, Vol. 1, 3-4.

[20] Barański, M. (1990) Preserving the Christian Basilica of El-Ashmunein. Ministère de l'Éducation nationale, de l'Enseignement supérieur et de la Recherche, Bifao, 41-49.

[21] Gaber, M.A.W. (2017) Characterizations of El Minia Limestone for Manufacturing Paper Filler and Coating. Egyptian Journal of Petroleum, 27, 437-443. https://doi.org/10.1016/j.ejpe.2017.07.007 
[22] El-Gohary, M.A. (2013) Analytical Investigations of Disintegrated Granite Surface from the Un-Finished Obelisk in Aswan. ArcheoSciences, 35, 34. http://archeosciences.revues.org/2909

[23] Carlton, R.A. (2011) Polarized Light Microscopy. Pharmaceutical Microscopy, 7-64. https://doi.org/10.1007/978-1-4419-8831-7_2

[24] Robertson, E.C. (1982) Physical Properties of Building Stone (Conservation of Historic Stone Buildings and Monuments). Committee on Conservation of Historic Stone Buildings and Monuments, National Materials Advisory Board, National Research Council. The National Academies Press, Washington DC, 62. http://nap.edu/514

[25] Altindag, R. (2012) Correlation between P-Wave Velocity and Some Mechanical Properties for Sedimentary Rocks. J.S.Afr.Inst.Min. Metall, 112.

[26] Liu, J.-C., Sue, M.-L. and Kou, C.-H. (2009) Estimating the Strength of Concrete Using Surface Rebound Value and Design Parameters of Concrete Material. Tamkang Journal of Science and Engineering, 12, 17.

[27] Hemeda, S., Akarish, A.I.M. and El-Nagga, A.A. (2018) Engineering Investigations and Durability Problems of the Construction Materials of the Roman Babylon of Egypt. Open Journal of Geology, 8, 404-436. https://doi.org/10.4236/ojg.2018.84024

[28] Hemeda, S. (2019) 3D Finite Element Coupled Analysis Model for Geotechnical andComplex Structural Problems of Historic Masonry Structures: Conservation of AbuSerga Church, Cairo, Egypt. Heritage Science, 7, 6.

https://doi.org/10.1186/s40494-019-0248-Z

[29] Hemeda, S. and El Moaty Atalaa, T.A. (2019) Intervention Retrofitting and Rehabilitation of Al-Gawhara Palace at the Saladin Citadel, Cairo, Egypt. Open Journal of Geology, 9, 109-141. https://doi.org/10.4236/ojg.2019.93009

[30] Hemeda, S., Fahmy, A. and Sonbol, A (2018) Geo-Environmental and Structural Problems of the First Successful True Pyramid, (Snefru Northern Pyramid) in Dahshur, Egypt. Geotechnical and Geological Engineering, 1-22. https://doi.org/10.1007/s10706-018-00769-x 